\title{
Design and Synthesis of Novel Isoxazole Tethered Quinone-Amino Acid Hybrids
}

\author{
P. Ravi Kumar, ${ }^{1,2}$ Manoranjan Behera, ${ }^{1}$ M. Sambaiah, ${ }^{1}$ Venu Kandula, ${ }^{1}$ \\ Nagaraju Payili, ${ }^{1}$ A. Jaya Shree, ${ }^{2}$ and Satyanarayana Yennam ${ }^{1}$ \\ ${ }^{1}$ Department of Medicinal Chemistry, GVK Biosciences Pvt. Ltd., Plot No. 28, IDA, Nacharam, Hyderabad, \\ Andhra Pradesh 500 076, India \\ ${ }^{2}$ Centre for Chemical Sciences \& Technology, Institute of Science and Technology, Jawaharlal Nehru Technological University, \\ Kukatpally, Hyderabad, Andhra Pradesh 500 072, India
}

Correspondence should be addressed to Manoranjan Behera; manoranjan.behera@gvkbio.com

Received 26 June 2014; Accepted 14 October 2014; Published 19 November 2014

Academic Editor: Sambasivarao Kotha

Copyright (C) 2014 P. Ravi Kumar et al. This is an open access article distributed under the Creative Commons Attribution License, which permits unrestricted use, distribution, and reproduction in any medium, provided the original work is properly cited.

\begin{abstract}
A new series of isoxazole tethered quinone-amino acid hybrids has been designed and synthesized involving 1,3-dipolar cycloaddition reaction followed by an oxidation reaction using cerium ammonium nitrate (CAN). Using this method, for the first time various isoxazole tethered quinone-phenyl alanine and quinone-alanine hybrids were synthesized from simple commercially available 4-bromobenzyl bromide, propargyl bromide, and 2,5-dimethoxybenzaldehyde in good yield.
\end{abstract}

\section{Introduction}

Compounds containing the quinone group present an important class of biologically active molecules that are widespread in nature [1-3]. The discoveries of antibiotic $[4,5]$ and antitumor [6] properties assigned to several natural quinones have raised interest among scientists for use as pharmaceuticals. While antibiotics display an enormous diversity in chemical structures, quinone antibiotics such as Adriamycin, Mitomycin C, and Streptonigrin deserve special attention [7-10]. In this context, search of new molecules containing quinone moiety has always fascinated the organic as well as medicinal chemist.

Isoxazole derivatives are an important class of heterocyclic pharmaceuticals and bioactive natural products because of their significant and wide spectrum of biological activities, including potent and selective antagonism of the NMDA receptor and anti-HIV activity $[11,12]$. It shows antihyperglycemic [13], analgesic [14], anti-inflammatory [15], antifungal [16], and antibacterial activity [17]. 3,5-Disubstituted isoxazole derivatives which are biological active include muscimol, dihydromuscimol, micafungin, and cycloserine
$[18,19]$. Unnatural amino acids, the nonproteinogenic $\alpha$ amino acids that occur either naturally or chemically synthesized, have been used widely as chiral building block. They have been also used as molecular scaffolds in constructing combinatorial libraries [20]. They represent a powerful tool in drug discovery when incorporated into therapeutic peptidomimetics and peptide analogs [21]. The seminal work on the synthesis of unnatural amino acids has been done by O'Donnell and Maruoka independently, which accelerated the application of this class of amino acid for practical applications [22, 23].

Synthesis of hybrid natural products has gained momentum in recent years [24-26]. It is expected that combining features of more than one biologically active natural segment in a single molecule may result in pronounced pharmacological activity while retaining high diversity and biological relevance. There are a few reports describing the preparation of quinone-hybrid with other natural products. For example, quinone-amino acids [27], sugar-oxasteroidquinone [28], quinone-annonaceous acetogenins [29], and conduritol-carba-sugar [30] hybrids have been described using different synthetic protocol. 
<smiles>Cc1onc(O)c1C[C@H](N)C(=O)O</smiles>

(S)-AMPA<smiles>CC(NC1=CC(=O)c2ccccc2C1=O)C(=O)O</smiles>

Katritzky et al.<smiles>CCOC(=O)C([AlH2])Cc1ccc2c(c1)C(=O)C(C)=C(C)C2=O</smiles>

Kotha et al.<smiles>CC(=O)NC1=CC(=O)C(N[C@@H](Cc2c[nH]c3ccccc23)C(=O)O)=CC1=O</smiles>

Abenquine D<smiles>CCCc1cc(C)cc(C)c1</smiles><smiles>C/C=C(\C)C(=O)N(C)[C@@H](Cc1ccccc1)C(=O)N[C@H](C(=O)NS(=O)(=O)CCCC)C(C)C</smiles>

Figure 1: Selected examples of amino acid hybrids.

In our continuation endeavour to prepare novel hybrid molecules containing variety of natural products [31], we developed interest in the synthesis of novel isoxazole tethered quinone-amino acid hybrid natural products, and herein we report our initial results. Depending on the hybrid pattern, hybrid molecules containing amino acids and either quinone or isoxazole were prepared by various groups using different methods (Figure 1). For example, AMPA ( $\alpha$-amino-3hydroxy-5-methyl-4-isoxazolepropionic acid) is a type of glutamatergic ion channels in the central nervous system which can be considered as isoxazole-amino acid hybrid. A series of novel AMPA analogues were prepared in order to evaluate it as drug candidates for neurological disorder [32]. Abenquine $\mathrm{D}$ is an amino acid quinone hybrid which is composed of an amino acid linked to an $\mathrm{N}$-acetyl-amino benzoquinone. Abenquines A-D are new bioactive secondary metabolites found in the fermentation broth of Streptomyces sp. stain DB634 which was isolated from the soils of Chilean highland of Atacama desert. The abenquines show inhibitory activity against bacteria, dermatophytic fungi, and phosphodiesterase type $\mathbf{4 b}$ [33]. It is noteworthy to mention here that amino acid attached to the quinone is relevant to the enzyme inhibitory activity. Similarly, IRL 3461 is a potent and bifunctional $\mathrm{ET}_{\mathrm{A}} / \mathrm{ET}_{\mathrm{B}}$ endothelin antagonist. IRL $346 \mathrm{a}$ is an isoxazoleamino acid hybrid prepared from 4-methyl-acetophenone in nine steps synthetic protocol [34]. Katritzky et al. have prepared naphthoquinone-amino acid conjugates starting from naphthoquinone and L-amino acids by a Michael type mechanism in aqueous ethanol solution at RT in the presence of triethylamine [35]. Kotha group has used a "building block approach" to synthesize the quinone-amino acid hybrids through ethylene cross-enyne metathesis and Diels-Alder reaction as the key step [27]. But there are no reports of isoxazole tethered quinone amino acid hybrids as per the literature search. To the best of our knowledge, this is the first report on the synthesis of new series of isoxazole tethered quinone-amino acid hybrid natural products.

In view of the importance of these three classes of natural products, we have designed a new class of hybrid structures 1 or $\mathbf{2}$ (Figure 2) in an effort to combine the activity of amino acid moiety and the quinone unit using isoxazole ring as linker. These hybrids may have significant biological activity and so an efficient strategy to these hybrid molecules would allow us to construct diverse hybrid analogues.

\section{Materials and Methods}

All reactions were carried out in oven-dried glassware with magnetic stirrers under an argon atmosphere. THF was dried over $\mathrm{Na}$ /benzophenone and DCM was dried over $\mathrm{CaH}_{2}$. Commercially available chemicals were purchased from Sigma-Aldrich and Alfa Aesar. EtOAc and pet ether were distilled before use. All melting points were taken in open capillaries and are uncorrected. Analytical thin-layer chromatography (TLC) was performed on commercially available Merck TLC Silica gel $60 \mathrm{~F}_{254}$. Silica gel column chromatography was performed on silica gel 60 (spherical $100-200 \mu \mathrm{m})$. FTIR spectra were recorded on Perkin-Elmer FT/IR-4000 spectrophotometer and only the characteristic peaks are reported. Mass spectra were scanned on a Shimadzu LCMS 2010 spectrometer. ${ }^{1} \mathrm{H}$ NMR spectra were recorded on Varian-400 (400 MHz) spectrometer. Chemical shifts of ${ }^{1} \mathrm{H}$ NMR spectra were reported relative to tetramethylsilane. 


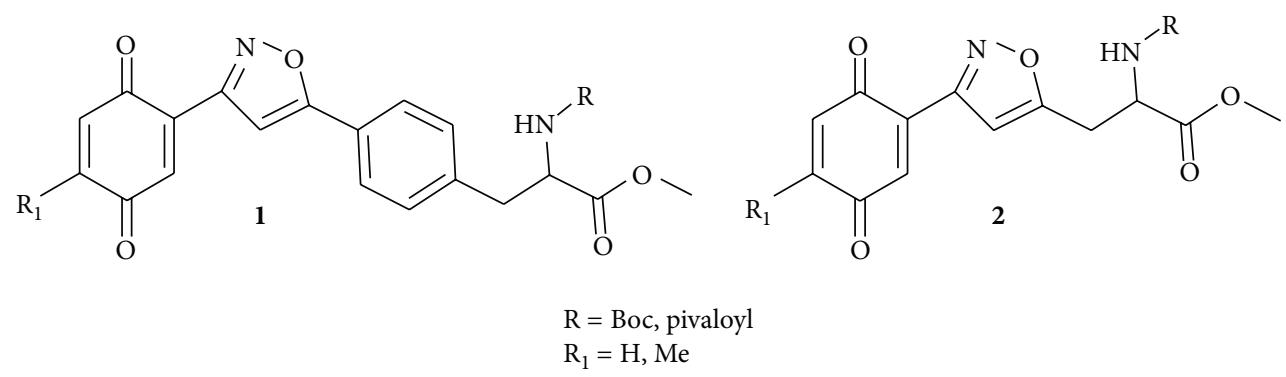

FIgURE 2: Isoxazole tethered quinone amino acid hybrid.

${ }^{13} \mathrm{C}$ NMR spectra were recorded on Varian-400 $(100 \mathrm{MHz})$ spectrometer. Chemical shifts of ${ }^{13} \mathrm{C}$ NMR spectra were reported to be relative to $\mathrm{CDCl}_{3}$ (77.0). Splitting patterns were reported as s, singlet; $d$, doublet; $t$, triplet; q, quartet; $m$, multiplet; dd, double doublet; and br, broad.

2.1. Experimental Procedure for the Preparation of Methyl 2((tert-Butoxycarbonyl)amino)-3-(4-((trimethylsilyl)ethynyl) phenyl)propanoate $(\mathbf{4 a})$. To a solution of compound $\mathbf{3 a}$ $(1.0 \mathrm{~g}, 2.80 \mathrm{mmol})$ in triethylamine $(10 \mathrm{~mL}), \mathrm{PdCl}_{2}\left(\mathrm{PPh}_{3}\right)_{2}$ $(0.098 \mathrm{~g}, 0.14 \mathrm{mmol})$, CuI $(0.013 \mathrm{~g}, 0.07 \mathrm{mmol})$, and trimethylsilylacetylene $(0.411 \mathrm{~g}, 4.20 \mathrm{mmol})$ were added under argon atmosphere and heated at $80^{\circ} \mathrm{C}$ in a sealed tube for $12 \mathrm{~h}$. The progress of the reaction was monitored by TLC analysis $(20 \%$ ethyl acetate/pet ether). After completion of the reaction, the reaction mixture was filtered. The filtrate was evaporated to give the crude product which was charged on silica gel column. The column was eluted with $20 \%$ ethyl acetate/pet ether to give the compound $4 \mathbf{a}(0.800 \mathrm{~g}, 76 \%$ yield $)$ as light yellow liquid.

IR $\left(\mathrm{KBr}, \mathrm{cm}^{-1}\right): 3375,2961,2158,1716,1505,1250,1168$, 865, 843. ${ }^{1} \mathrm{H}$ NMR $\left(400 \mathrm{MHz}, \mathrm{CDCl}_{3}\right): \delta=7.42-7.36(\mathrm{~m}, 2 \mathrm{H})$, $7.06(\mathrm{~d}, J=7.8 \mathrm{~Hz}, 2 \mathrm{H}), 4.94(\mathrm{~d}, J=8.1 \mathrm{~Hz}, 1 \mathrm{H}), 4.57(\mathrm{~d}, J=$ $7.4 \mathrm{~Hz}, 1 \mathrm{H}), 3.69(\mathrm{~s}, 3 \mathrm{H}), 3.09(\mathrm{td}, J=14.2,6.1 \mathrm{~Hz}, 2 \mathrm{H}), 1.42(\mathrm{~s}$, 9H), 0.2 (s, 9H). MS (EI): $m / z 375(\mathrm{M}+1,100)$.

2.2. Experimental Procedure for the Preparation of Methyl 2Pivalamido-3-(4-((trimethylsilyl)ethynyl)phenyl)propanoate (4b). To a solution of compound $3 \mathbf{b}(3.5 \mathrm{~g}, 10.26 \mathrm{mmol})$ in triethylamine $(20 \mathrm{~mL}), \mathrm{PdCl}_{2}\left(\mathrm{PPh}_{3}\right)_{2}(0.359 \mathrm{~g}, 0.51 \mathrm{mmol})$, $\mathrm{CuI}(0.048 \mathrm{~g}, 0.25 \mathrm{mmol})$, and trimethylsilylacetylene $(1.20 \mathrm{~g}$, $12.31 \mathrm{mmol}$ ) were added under argon atmosphere and heated at $90^{\circ} \mathrm{C}$ in a sealed tube for $12 \mathrm{~h}$. The progress of the reaction was monitored by TLC analysis (30\% ethyl acetate/pet ether). After completion of the reaction, the reaction mixture was filtered. The filtrate was evaporated to give the crude reaction mixture which was charged on silica gel column. The column was eluted with $20 \%$ ethyl acetate/pet ether to give the compound $\mathbf{4 b}$ (1.8 g, $48 \%$ yield) as off-white solid.

m.p. $143-145^{\circ} \mathrm{C}$. IR $\left(\mathrm{KBr}, \mathrm{cm}^{-1}\right)$ : 3328, 2958, 2158, 1751, $1638,1205,841 .{ }^{1} \mathrm{H}$ NMR (300 MHz, DMSO): $\delta=7.40$ (dd, $J=1.7,7.8 \mathrm{~Hz}, 2 \mathrm{H}), 7.20(\mathrm{dd}, J=10.3,8.1 \mathrm{~Hz}, 2 \mathrm{H}), 4.53-4.38$ (m, $1 \mathrm{H}), 3.61(\mathrm{~d}, J=1.7 \mathrm{~Hz}, 3 \mathrm{H}), 3.18-2.89(\mathrm{~m}, 2 \mathrm{H}), 1.00(\mathrm{~d}, J$ $=1.6 \mathrm{~Hz}, 9 \mathrm{H}), 0.2(\mathrm{~s}, 9 \mathrm{H})$. MS (EI): $m / z 360(\mathrm{M}+1,100)$.
2.3. Experimental Procedure for the Preparation of Methyl 2((tert-Butoxycarbonyl)amino)-3-(4-ethynylphenyl)propanoate $(5 \boldsymbol{a})$. To a solution of compound $4 \mathrm{a}(0.800 \mathrm{~g}, 2.13 \mathrm{mmol})$ in THF $(10 \mathrm{~mL}), 1 \mathrm{M}$ TBAF in THF $(4.26 \mathrm{~mL}, 4.26 \mathrm{mmol})$ was added at $-70^{\circ} \mathrm{C}$ and stirred for $2 \mathrm{~h}$. The progress of the reaction was monitored by TLC analysis (20\% ethyl acetate/pet ether). After the reaction was complete, the reaction mixture was quenched with water $(10 \mathrm{~mL})$ and extracted with ethyl acetate thrice. The organic layers were combined and washed with water, brined, and dried over anhydrous $\mathrm{Na}_{2} \mathrm{SO}_{4}$. Evaporation of the solvent in high vacuum gave the compound $\mathbf{5 a}(0.650 \mathrm{~g}, 95 \%$ yield $)$ as light yellow solid.

m.p. $94-97^{\circ} \mathrm{C}$. IR $\left(\mathrm{KBr}, \mathrm{cm}^{-1}\right): 3355,2974,2103,1739,1682$, 1519, 1170, 826. ${ }^{1} \mathrm{H}$ NMR $\left(400 \mathrm{MHz}, \mathrm{CDCl}_{3}\right): \delta=7.42(\mathrm{~d}, J=$ $7.8 \mathrm{~Hz}, 2 \mathrm{H}), 7.09$ (d, $J=7.8 \mathrm{~Hz}, 2 \mathrm{H}), 4.96(\mathrm{~s}, 1 \mathrm{H}), 4.58$ (d, $J=$ $7.8 \mathrm{~Hz}, 1 \mathrm{H}), 3.71(\mathrm{~d}, J=1.0 \mathrm{~Hz}, 3 \mathrm{H}), 3.21-2.94(\mathrm{~m}, 3 \mathrm{H}), 1.42$ (s, 9H). MS (EI): $m / z 303(\mathrm{M}+1,100)$.

2.4. Experimental Procedure for the Preparation of Methyl 3(4-Ethynylphenyl)-2-pivalamidopropanoate (5b). To a solution of compound $\mathbf{4 b}(1.0 \mathrm{~g}, 3.84 \mathrm{mmol})$ in THF $(20 \mathrm{~mL}), 1 \mathrm{M}$ TBAF in THF $(3.8 \mathrm{~mL}, 7.66 \mathrm{mmol})$ was added at $-70^{\circ} \mathrm{C}$ and stirred for $2 \mathrm{~h}$. The progress of the reaction was monitored by TLC analysis (20\% ethyl acetate/pet ether). After the reaction was complete, the reaction mixture was quenched with water $(20 \mathrm{~mL})$ and extracted with ethyl acetate thrice. The organic layers were combined, washed with water, brined, and dried over anhydrous $\mathrm{Na}_{2} \mathrm{SO}_{4}$. Evaporation of the solvent in high vacuum gave the compound $\mathbf{5 b}(0.650 \mathrm{~g}, 82 \%$ yield $)$ as offwhite solid.

m.p. $65-68^{\circ} \mathrm{C} . \mathrm{IR}\left(\mathrm{KBr}, \mathrm{cm}^{-1}\right): 3326,2957,1750,1737,1637$, 1522, 1202, 1116. ${ }^{1} \mathrm{H}$ NMR (400 MHz, DMSO): $\delta=7.39-7.33$ (m, 2H), 7.27-7.20 (m, 2H), $4.46(\mathrm{~m}, 1 \mathrm{H}), 4.12(\mathrm{~s}, 1 \mathrm{H}), 3.61(\mathrm{~s}$, $3 \mathrm{H}), 3.18-2.90(\mathrm{~m}, 2 \mathrm{H}), 1.00(\mathrm{~d}, J=2.2 \mathrm{~Hz}, 9 \mathrm{H})$. MS (EI): $\mathrm{m} / z$ $288(\mathrm{M}+1,100)$.

2.5. Experimental Procedure for the Preparation of 2,5Dimethoxybenzaldehyde Oxime (7a). To a solution of compound 6a (1 g, $6.02 \mathrm{mmol})$ in $\mathrm{MeOH}(10 \mathrm{~mL}), \mathrm{NaOAc}(0.98 \mathrm{~g}$, $12.04 \mathrm{mmol})$ and $\mathrm{NH}_{2} \mathrm{OH} \cdot \mathrm{HCl}(0.62 \mathrm{~g}, 9.03 \mathrm{mmol})$ were added under nitrogen atmosphere. Then the reaction mixture was stirred at RT for $2 \mathrm{~h}$. The progress of the reaction was monitored by TLC analysis (20\% ethyl acetate/pet ether). 
After completion of the reaction, the solvent was evaporated, quenched with water $(20 \mathrm{~mL})$, and extracted with ethyl acetate thrice. The organic layers were combined, washed with water, brined, and dried over anhydrous $\mathrm{Na}_{2} \mathrm{SO}_{4}$. Evaporation of the solvent in high vacuum gave the compound $7 \mathbf{a}$ (1.0 g, 91\% yield) as off-white solid.

m.p. $105-107^{\circ} \mathrm{C}$. IR $\left(\mathrm{KBr}, \mathrm{cm}^{-1}\right)$ : $3245,2838,1577,1503$, $1277,1232,1038,970 .{ }^{1} \mathrm{H}$ NMR $\left(400 \mathrm{MHz} \mathrm{CDCl}_{3}\right): \delta=8.5(\mathrm{~s}$, $1 \mathrm{H}), 7.6-8.0$ (br s, $1 \mathrm{H}), 7.3(\mathrm{~m}, 1 \mathrm{H}), 6.9(\mathrm{~m}, 1 \mathrm{H}), 6.8(\mathrm{~m}, 1 \mathrm{H})$, 3.8 (s, 3H), 3.7 (s, 3H). MS (EI): $m / z 181\left(\mathrm{M}^{+}, 100\right)$.

2.6. Experimental Procedure for the Preparation of 2,5Dimethoxy-4-methylbenzaldehyde Oxime (7b). To a solution of compound $\mathbf{6 b}(3.0 \mathrm{~g}, 16.6 \mathrm{mmol})$ in $\mathrm{MeOH}(30 \mathrm{~mL})$, $\mathrm{NaOAc}(2.73 \mathrm{~g}, 33.3 \mathrm{mmol})$ and $\mathrm{NH}_{2} \mathrm{OH} \cdot \mathrm{HCl}(1.73 \mathrm{~g}$, $24.9 \mathrm{mmol}$ ) were added under nitrogen atmosphere. Then the reaction mixture was stirred at RT for $2 \mathrm{~h}$. The progress of the reaction was monitored by TLC analysis (20\% ethyl acetate/pet ether). After completion of the reaction, the solvent was evaporated, quenched with water $(20 \mathrm{~mL})$, and extracted with ethyl acetate thrice. The organic layers were combined, washed with water, brined, and dried over anhydrous $\mathrm{Na}_{2} \mathrm{SO}_{4}$. Evaporation of the solvent in high vacuum gave the compound $7 \mathbf{b}(3.05 \mathrm{~g}, 93 \%$ yield $)$ as off-white solid.

m.p. $125-129^{\circ}$ C. IR $\left(\mathrm{KBr}, \mathrm{cm}^{-1}\right)$ : 3187, 2995, 1613, 1405, $1212,1045 .{ }^{1} \mathrm{H}$ NMR $\left(400 \mathrm{MHz}, \mathrm{CDCl}_{3}\right): \delta=11.10(\mathrm{~s}, 1 \mathrm{H}), 8.20$ (s, 1H), 7.15 (s, 1H), 6.9 (s, 1H), 3.75 (s, 6H), 2.2 (s, 3H). MS (EI): $m / z 195\left(\mathrm{M}^{+}, 100\right)$.

2.7. Experimental Procedure for the Preparation of Methyl 2((tert-Butoxycarbonyl)amino)-3-(4-(3-(2,5-dimethoxyphenyl) isoxazol-5-yl)phenyl)propanoate $(\mathbf{8 a})$. To a solution of compound $7 \mathbf{a}(0.150 \mathrm{~g}, 0.83 \mathrm{mmol})$ in dichloromethane $(8 \mathrm{~mL})$, compound $5 \mathrm{a}(0.27 \mathrm{~g}, 0.91 \mathrm{mmol})$, triethylamine $(0.12 \mathrm{~g}$, $1.24 \mathrm{mmol})$, and $\mathrm{NaOCl}\left(9-12 \%\right.$ in $\left.\mathrm{H}_{2} \mathrm{O}, 8 \mathrm{~mL}\right)$ were added at $0^{\circ} \mathrm{C}$ under nitrogen atmosphere. Then the reaction mixture was stirred at RT for $12 \mathrm{~h}$. The progress of the reaction was monitored by TLC analysis (30\% ethyl acetate/pet ether). After completion of the reaction, the solvent was evaporated, quenched with water $(20 \mathrm{~mL})$, and extracted with dichloromethane. The organic layers were combined, washed with water, brined, and dried over anhydrous $\mathrm{Na}_{2} \mathrm{SO}_{4}$. Evaporation of the solvent in high vacuum gave the compound $8 \mathbf{a}(0.28 \mathrm{~g}, 71 \%$ yield) as light yellow liquid.

IR $\left(\mathrm{KBr}, \mathrm{cm}^{-1}\right): 3304,2970,2939,1712,1627,1500,1276$, 1222, 1170, 1045. ${ }^{1} \mathrm{H}$ NMR $\left(300 \mathrm{MHz}, \mathrm{CDCl}_{3}\right): \delta=7.78(\mathrm{~d}, J=$ $8.0 \mathrm{~Hz}, 2 \mathrm{H}), 7.59-7.48(\mathrm{~m}, 1 \mathrm{H}), 7.24(\mathrm{~s}, 2 \mathrm{H}), 7.04(\mathrm{~s}, 1 \mathrm{H}), 6.98$ $(\mathrm{t}, J=1.8 \mathrm{~Hz}, 2 \mathrm{H}), 5.00(\mathrm{~s}, 1 \mathrm{H}), 4.62(\mathrm{~s}, 1 \mathrm{H}), 3.97-3.63(\mathrm{~m}, 9 \mathrm{H})$, $3.22(\mathrm{~d}, J=3.1 \mathrm{~Hz}, 2 \mathrm{H}), 1.42$ (s, 9H). MS (EI): $m / z 482(\mathrm{M}+1$, 100).

2.8. Experimental Procedure for the Preparation of Methyl 3-(4-(3-(2,5-Dimethoxyphenyl)isoxazol-5-yl)phenyl)-2-pivalamidopropanoate $(\mathbf{8 b})$. To a solution of compound $7 \mathbf{a}$ $(0.2 \mathrm{~g}, 1.11 \mathrm{mmol})$ in dichloromethane $(10 \mathrm{~mL})$, compound $5 \mathbf{b}$ $(0.35 \mathrm{~g}, 1.22 \mathrm{mmol})$, triethylamine $(0.16 \mathrm{~g}, 1.66 \mathrm{mmol})$, and $\mathrm{NaOCl}(9-12 \%$ in water, $10 \mathrm{~mL})$ were added at $0^{\circ} \mathrm{C}$ under nitrogen atmosphere. Then the reaction mixture was stirred at RT for $12 \mathrm{~h}$. The progress of the reaction was monitored by TLC analysis (30\% ethyl acetate/pet ether). After completion of the reaction, the solvent was evaporated, quenched with water $(20 \mathrm{~mL})$, and extracted with dichloromethane. The organic layers were combined, washed with water, brined, and dried over anhydrous $\mathrm{Na}_{2} \mathrm{SO}_{4}$. Evaporation of the solvent gives the crude reaction mixture which was charged on silica gel column. The column was eluted with $25 \%$ ethyl acetate/pet ether to give the compound $\mathbf{8 b}$ ( $0.3 \mathrm{~g}, 58 \%$ yield) as light yellow liquid.

IR (KBr, cm $\left.{ }^{-1}\right): 3437,2926,1623,1275,1260,764,750 .{ }^{1} \mathrm{H}$ $\operatorname{NMR}\left(300 \mathrm{MHz}, \mathrm{CDCl}_{3}\right): \delta=7.82-7.73(\mathrm{~m}, 2 \mathrm{H}), 7.55-7.47(\mathrm{~m}$, $1 \mathrm{H}), 7.24-7.16(\mathrm{~m}, 2 \mathrm{H}), 7.05(\mathrm{~s}, 1 \mathrm{H}), 6.98(\mathrm{t}, J=1.9 \mathrm{~Hz}, 2 \mathrm{H})$, $6.12(\mathrm{~d}, J=7.5 \mathrm{~Hz}, 1 \mathrm{H}), 4.90(\mathrm{dt}, J=7.5,5.8 \mathrm{~Hz}, 1 \mathrm{H}), 3.89(\mathrm{~s}$, $3 \mathrm{H}), 3.84$ (s, 3H), 3.81-3.74 (m, 3H), 3.33-3.07 (m, 2H), 1.17 $(\mathrm{s}, 9 \mathrm{H}) .{ }^{13} \mathrm{C} \mathrm{NMR}\left(100 \mathrm{MHz}, \mathrm{CDCl}_{3}\right): \delta_{\mathrm{C}} 177.9,172.0,169.0$, $160.4,153.6,151.6,138.0,129.8,126.6,125.8,118.4,117.3,114.9$, $113.5,113.0,112.4,100.9,56.2,55.8,52.7,52.4,42.7,38.7,38.6$, 37.7, 29.6. HRMS (ESI): Calcd for $\mathrm{C}_{26} \mathrm{H}_{31} \mathrm{~N}_{2} \mathrm{O}_{6}[\mathrm{M}+\mathrm{H}]^{+}$: 467.2182; Found: 467.2455.

2.9. Experimental Procedure for the Preparation of Methyl 2((tert-Butoxycarbonyl)amino)-3-(4-(3-(2,5-dimethoxy-4-meth$y$ lphenyl)isoxazol-5-yl)phenyl)propanoate (8c). To a solution of compound $7 \mathbf{b}(0.2 \mathrm{~g}, 1.02 \mathrm{mmol})$ in dichloromethane $(10 \mathrm{~mL})$, compound $5 \mathbf{a}(0.34 \mathrm{~g}, 1.12 \mathrm{mmol})$, triethylamine $(0.15 \mathrm{~g}, 1.53 \mathrm{mmol})$, and $\mathrm{NaOCl}\left(9-12 \%\right.$ in $\left.\mathrm{H}_{2} \mathrm{O}, 10 \mathrm{~mL}\right)$ were added at $0^{\circ} \mathrm{C}$ under nitrogen atmosphere. Then the reaction mixture was stirred at $\mathrm{RT}$ for $12 \mathrm{~h}$. The progress of the reaction was monitored by TLC analysis (30\% ethyl acetate/pet ether). After completion of the reaction, water $(20 \mathrm{~mL})$ was added and extracted with dichloromethane thrice. The organic layers were combined, washed with water, brined, and dried over anhydrous $\mathrm{Na}_{2} \mathrm{SO}_{4}$. The solvent was evaporated to give the crude reaction mixture which was charged on silica gel column. Elution of the column with $20 \%$ ethyl acetate/pet ether gave the compound $8 \mathrm{c}(0.41 \mathrm{~g}$, $80 \%$ yield) as off-white solid.

m.p $147-150^{\circ} \mathrm{C}$. IR $\left(\mathrm{KBr}, \mathrm{cm}^{-1}\right): 3373,3149,2932,1742$, $1702,1520,1216,1044 .{ }^{1} \mathrm{H}$ NMR $\left(300 \mathrm{MHz} \mathrm{CDCl}_{3}\right): \delta=7.78$ (d, $J=7.8 \mathrm{~Hz}, 2 \mathrm{H}), 7.45$ (s, 1H), $7.26(\mathrm{~d}, J=1.4 \mathrm{~Hz}, 2 \mathrm{H}), 7.06$ (s, 1H), $6.85(\mathrm{~s}, 1 \mathrm{H}), 5.03(\mathrm{~d}, J=8.4 \mathrm{~Hz}, 1 \mathrm{H}), 4.63(\mathrm{q}, J=$ $6.7 \mathrm{~Hz}, 1 \mathrm{H}), 3.87$ (d, $J=4.6 \mathrm{~Hz}, 6 \mathrm{H}), 3.73$ (s, 3H), 3.17 (td, $J$ $=16.2,15.0,5.8 \mathrm{~Hz}, 2 \mathrm{H}), 2.28(\mathrm{~s}, 3 \mathrm{H}), 1.42(\mathrm{~s}, 9 \mathrm{H}) .{ }^{13} \mathrm{C} \mathrm{NMR}$ $\left(100 \mathrm{MHz}, \mathrm{CDCl}_{3}\right): \delta_{\mathrm{C}} 172.0,168.9,160.5,155.0,151.9,151.1$, $138.1,130.0,129.8,126.6,125.9,115.3,115.0,110.3,100.9,80.0$, 56.3, 55.9, 54.2, 52.3, 38.3, 28.2, 16.6. MS (EI) $m / z 496(\mathrm{M}+1$, 100). HRMS (ESI): Calcd for $\mathrm{C}_{27} \mathrm{H}_{33} \mathrm{~N}_{2} \mathrm{O}_{7}[\mathrm{M}+\mathrm{H}]^{+}$: 497.1882; Found: 497.2288 .

2.10. Experimental Procedure for the Preparation of Methyl 3(4-(3-(2,5-Dimethoxy-4-methylphenyl)isoxazol-5-yl)phenyl)2-pivalamidopropanoate $(\mathbf{8 d})$. To a solution of compound $\mathbf{7 b}$ $(0.15 \mathrm{~g}, 0.76 \mathrm{mmol})$ in dichloromethane $(10 \mathrm{~mL})$, compound 5b $(0.24 \mathrm{~g}, 0.84 \mathrm{mmol})$, triethylamine $(0.116 \mathrm{~g}, 1.15 \mathrm{mmol})$, and $\mathrm{NaOCl}(9-12 \%$ in water, $10 \mathrm{~mL})$ were added at $0^{\circ} \mathrm{C}$ under nitrogen atmosphere. Then the reaction mixture was stirred 
at RT for $12 \mathrm{~h}$. The progress of the reaction was monitored by TLC analysis (30\% ethyl acetate/pet ether). After completion of the reaction, water $(10 \mathrm{~mL})$ was added and the reaction mixture was extracted with dichloromethane thrice. The organic layers were combined, washed with water, brined, and dried over anhydrous $\mathrm{Na}_{2} \mathrm{SO}_{4}$. The solvent was evaporated to give the crude reaction which was charged on silica gel column. Elution of the column with $25 \%$ ethyl acetate/pet ether gave the compound $8 \mathbf{d}$ ( $0.31 \mathrm{~g}, 83 \%$ yield) as light yellow liquid.

IR $\left(\mathrm{KBr}, \mathrm{cm}^{-1}\right)$ : 3444, 2929, 1637, 1473, 1275, 1261, 1215, 764. ${ }^{1} \mathrm{H}$ NMR ( $\left.300 \mathrm{MHz}, \mathrm{DMSO}\right): \delta=7.81(\mathrm{dd}, J=13.0$, $8.0 \mathrm{~Hz}, 3 \mathrm{H}), 7.41(\mathrm{~d}, J=8.1 \mathrm{~Hz}, 2 \mathrm{H}), 7.32(\mathrm{~d}, J=3.3 \mathrm{~Hz}, 2 \mathrm{H})$, $7.07(\mathrm{~s}, 1 \mathrm{H}), 4.51(\mathrm{~s}, 1 \mathrm{H}), 3.85(\mathrm{~s}, 3 \mathrm{H}), 3.80(\mathrm{~s}, 3 \mathrm{H}), 3.64(\mathrm{~s}, 3 \mathrm{H})$, 3.24-2.96 (m, 2H), $2.20(\mathrm{~d}, J=19.4 \mathrm{~Hz}, 3 \mathrm{H}), 1.02(\mathrm{~s}, 9 \mathrm{H})$. MS (EI): $m / z 480(\mathrm{M}+1,100)$.

2.11. Experimental Procedure for the Preparation of Methyl 2((tert-Butoxycarbonyl)amino)-3-(4-(3-(3,6-dioxocyclohexa-1, 4-dien-1-yl)isoxazol-5-yl)phenyl)propanoate (9a). To a solution of compound $\mathbf{8 a}(0.15 \mathrm{~g}, 0.31 \mathrm{mmol})$ in acetonitrile $(6 \mathrm{~mL})$ and $\mathrm{H}_{2} \mathrm{O}(1 \mathrm{~mL})$, CAN $(0.511 \mathrm{~g}, 0.93 \mathrm{mmol})$ was added and the reaction mixture was stirred at RT for $1 \mathrm{~h}$. The progress of the reaction was monitored by TLC analysis $(30 \%$ ethyl acetate/pet ether). After completion of the reaction, water $(10 \mathrm{~mL})$ was added and extracted with ethyl acetate thrice. The organic layers were combined, washed with water, brined, and dried over anhydrous $\mathrm{Na}_{2} \mathrm{SO}_{4}$. Evaporation of the solvent in high vacuum gave the compound $9 \mathrm{a}(0.12 \mathrm{~g}$, $85 \%$ yield) as yellow solid.

m.p. $125-127^{\circ} \mathrm{C}$. IR $\left(\mathrm{KBr}, \mathrm{cm}^{-1}\right): 3355,2979,1743,1720$, 1654, 1522, 1288, 1251, 1167. ${ }^{1} \mathrm{H}$ NMR $\left(300 \mathrm{MHz}, \mathrm{CDCl}_{3}\right): \delta=$ $7.77(\mathrm{~d}, J=7.9 \mathrm{~Hz}, 2 \mathrm{H}), 7.48(\mathrm{~d}, J=1.9 \mathrm{~Hz}, 1 \mathrm{H}), 7.26(\mathrm{~d}, J=$ $0.9 \mathrm{~Hz}, 2 \mathrm{H}), 7.12(\mathrm{~d}, J=0.9 \mathrm{~Hz}, 1 \mathrm{H}), 6.96-6.86(\mathrm{~m}, 2 \mathrm{H}), 5.02$ $(\mathrm{s}, 1 \mathrm{H}), 4.63(\mathrm{~s}, 1 \mathrm{H}), 3.74(\mathrm{~d}, J=1.0 \mathrm{~Hz}, 3 \mathrm{H}), 3.29-3.02(\mathrm{~m}, 2 \mathrm{H})$, $1.42(\mathrm{~s}, 9 \mathrm{H}) .{ }^{13} \mathrm{C}$ NMR $\left(100 \mathrm{MHz}, \mathrm{CDCl}_{3}\right): \delta_{\mathrm{C}} 186.8,185.2$, $171.9,170.7,156.5,154.9,139.0,136.8,136.6,134.4,133.3,130.0$, 126.0, 125.7, 100.7, 80.1, 54.2, 52.3, 38.3, 28.2. HRMS (ESI): Calcd for $\mathrm{C}_{24} \mathrm{H}_{24} \mathrm{~N}_{2} \mathrm{O}_{7}[\mathrm{M}+\mathrm{H}]^{+}$: 453.1662; Found: 453.1640 .

2.12. Experimental Procedure for the Preparation of Methyl 3-(4-(3-(3,6-Dioxocyclohexa-1,4-dien-1-yl)isoxazol-5-yl)phenyl)-2-pivalamidopropanoate (9b). To a solution of compound $8 \mathbf{b}(0.2 \mathrm{~g}, 0.42 \mathrm{mmol})$ in acetonitrile $(8 \mathrm{~mL})$ and $\mathrm{H}_{2} \mathrm{O}(2 \mathrm{~mL})$, CAN $(0.705 \mathrm{~g}, 1.28 \mathrm{mmol})$ was added and the reaction mixture was stirred at RT for $1 \mathrm{~h}$. The progress of the reaction was monitored by TLC analysis (30\% ethyl acetate/pet ether). After completion of the reaction, water $(20 \mathrm{~mL})$ was added and extracted with ethyl acetate thrice. The organic layers were combined, washed with water, brined, and dried over anhydrous $\mathrm{Na}_{2} \mathrm{SO}_{4}$. Evaporation of the solvent in high vacuum gave the compound $\mathbf{9 b}(0.136 \mathrm{~g}$, $72 \%$ yield) as yellow solid.

m.p. $115-117^{\circ} \mathrm{C}$. IR $\left(\mathrm{KBr}, \mathrm{cm}^{-1}\right)$ : 3321, 2958, 1749, 1656, 1640, 1531, 1286, 1199, 1107. ${ }^{1} \mathrm{H}$ NMR $\left(300 \mathrm{MHz}, \mathrm{CDCl}_{3}\right) \delta=$ $7.76(\mathrm{~d}, J=7.9 \mathrm{~Hz}, 2 \mathrm{H}), 7.47(\mathrm{~d}, J=2.2 \mathrm{~Hz}, 1 \mathrm{H}), 7.23(\mathrm{~d}, J=$ $7.9 \mathrm{~Hz}, 2 \mathrm{H}), 7.12(\mathrm{~s}, 1 \mathrm{H}), 6.90(\mathrm{~d}, J=2.7 \mathrm{~Hz}, 2 \mathrm{H}), 6.13(\mathrm{~d}, J=$ $7.7 \mathrm{~Hz}, 1 \mathrm{H}), 4.90(\mathrm{q}, J=6.1 \mathrm{~Hz}, 1 \mathrm{H}), 3.77(\mathrm{~s}, 3 \mathrm{H}), 3.37-3.04(\mathrm{~m}$,
2H), 1.17 (s, 9H). ${ }^{13} \mathrm{C} \mathrm{NMR}\left(100 \mathrm{MHz}, \mathrm{CDCl}_{3}\right): \delta_{\mathrm{C}} 186.8,185.1$, 177.9, 172.0, 170.6, 156.5, 138.9, 136.8, 136.6, 134.4, 133.3, 130.0, 125.9, 125.7, 100.7, 52.7, 52.4, 38.6, 37.7, 27.3. HRMS (ESI): Calcd for $\mathrm{C}_{24} \mathrm{H}_{25} \mathrm{~N}_{2} \mathrm{O}_{6}[\mathrm{M}+\mathrm{H}]^{+}$: 437.1713; Found: 437.1879.

2.13. Experimental Procedure for the Preparation of Methyl 2((tert-Butoxycarbonyl)amino)-3-(4-(3-(4-methyl-3,6-dioxocyclohexa-1,4-dien-1-yl)isoxazol-5-yl)phenyl)propanoate (9c). To a solution of compound $8 \mathrm{c}(0.23 \mathrm{~g}, 0.46 \mathrm{mmol})$ in acetonitrile $(10 \mathrm{~mL})$ and $\mathrm{H}_{2} \mathrm{O}(2 \mathrm{~mL})$, CAN $(0.76 \mathrm{~g}$, $1.39 \mathrm{mmol}$ ) was added and the reaction mixture was stirred at RT for $1 \mathrm{~h}$. The progress of the reaction was monitored by TLC analysis (30\% ethyl acetate/pet ether). After completion of the reaction, water $(20 \mathrm{~mL})$ was added and extracted with ethyl acetate thrice. The organic layers were combined, washed with water, brined, and dried over anhydrous $\mathrm{Na}_{2} \mathrm{SO}_{4}$. Evaporation of the solvent in high vacuum gave the compound $9 \mathrm{c}(0.205 \mathrm{~g}, 95 \%$ yield $)$ as yellow solid.

m.p. $153-155^{\circ} \mathrm{C}$. IR $\left(\mathrm{KBr}, \mathrm{cm}^{-1}\right): 3364,2979,1732,1693$, $1660,1524,1252,1170,1020 .{ }^{1} \mathrm{H}$ NMR $\left(300 \mathrm{MHz}, \mathrm{CDCl}_{3}\right): \delta=$ 7.83-7.69 (m, 2H), $7.45(\mathrm{~s}, 1 \mathrm{H}), 7.34-7.20(\mathrm{~m}, 2 \mathrm{H}), 7.11(\mathrm{~s}, 1 \mathrm{H})$, $6.74(\mathrm{q}, J=1.5 \mathrm{~Hz}, 1 \mathrm{H}), 5.04(\mathrm{~d}, J=8.1 \mathrm{~Hz}, 1 \mathrm{H}), 4.63(\mathrm{q}, J=$ $6.7 \mathrm{~Hz}, 1 \mathrm{H}), 3.74(\mathrm{~s}, 3 \mathrm{H}), 3.29-3.00(\mathrm{~m}, 2 \mathrm{H}), 2.13(\mathrm{~d}, J=1.6 \mathrm{~Hz}$, $3 \mathrm{H}), 1.42(\mathrm{~s}, 9 \mathrm{H}) .{ }^{13} \mathrm{CNMR}\left(100 \mathrm{MHz}, \mathrm{CDCl}_{3}\right): \delta_{\mathrm{C}} 187.4,185.4$, $171.9,170.5,156.5,154.9,146.2,138.9,134.3,133.5,133.4,130.0$, $126.0,125.7,100.8,80.1,54.2,52.3,38.3,28.2,15.5$. HRMS (ESI): Calcd for $\mathrm{C}_{25} \mathrm{H}_{27} \mathrm{~N}_{2} \mathrm{O}_{7}[\mathrm{M}+\mathrm{H}]^{+}$: 467.1818; Found: 467.1611.

2.14. Experimental Procedure for the Preparation of Methyl 3-(4-(3-(4-Methyl-3,6-dioxocyclohexa-1,4-dien-1-yl)isoxazol5-yl)phenyl)-2-pivalamidopropanoate (9d). To a solution of compound $8 \mathbf{d}(0.3 \mathrm{~g}, 0.62 \mathrm{mmol})$ in acetonitrile $(12 \mathrm{~mL})$ and $\mathrm{H}_{2} \mathrm{O}(3 \mathrm{~mL})$, CAN $(1.02 \mathrm{~g}, 1.86 \mathrm{mmol})$ was added and the reaction mixture was stirred at RT for $1 \mathrm{~h}$. The progress of the reaction was monitored by TLC analysis (30\% ethyl acetate/pet ether). After completion of the reaction, water $(20 \mathrm{~mL})$ was added and extracted with ethyl acetate thrice. The organic layers were combined, washed with water, brined, and dried over anhydrous $\mathrm{Na}_{2} \mathrm{SO}_{4}$. Evaporation of the solvent in high vacuum gave the compound $9 \mathrm{~d}(0.25 \mathrm{~g}$, $89 \%$ yield) as yellow solid.

m.p. $130-132^{\circ} \mathrm{C}$. IR $\left(\mathrm{KBr}, \mathrm{cm}^{-1}\right): 3379,2959,2924,1734$, $1657,1237,1020,807 .{ }^{1} \mathrm{H}$ NMR $\left(300 \mathrm{MHz}, \mathrm{CDCl}_{3}\right): \delta=7.82-$ $7.68(\mathrm{~m}, 2 \mathrm{H}), 7.45(\mathrm{~d}, J=1.3 \mathrm{~Hz}, 1 \mathrm{H}), 7.22(\mathrm{~d}, J=7.9 \mathrm{~Hz}, 2 \mathrm{H})$, $7.12(\mathrm{~d}, J=1.0 \mathrm{~Hz}, 1 \mathrm{H}), 6.74(\mathrm{q}, J=1.4 \mathrm{~Hz}, 1 \mathrm{H}), 6.12(\mathrm{~d}, J$ $=7.4 \mathrm{~Hz}, 1 \mathrm{H}), 4.90(\mathrm{q}, J=6.2 \mathrm{~Hz}, 1 \mathrm{H}), 3.76(\mathrm{~d}, J=0.9 \mathrm{~Hz}$, $3 \mathrm{H}), 3.34-3.05(\mathrm{~m}, 2 \mathrm{H}), 2.18-2.07(\mathrm{~m}, 3 \mathrm{H}), 1.17(\mathrm{~d}, J=0.9 \mathrm{~Hz}$, $9 \mathrm{H}) .{ }^{13} \mathrm{C} \mathrm{NMR}\left(100 \mathrm{MHz}, \mathrm{CDCl}_{3}\right): \delta_{\mathrm{C}} 187.3,185.4,177.9,172.0$, $170.4,156.5,146.2,138.8,134.2,133.5,133.4,130.0,125.9,125.8$, 100.9, 52.7, 52.4, 38.6, 37.7, 27.3, 15.5. HRMS (ESI): Calcd for $\mathrm{C}_{25} \mathrm{H}_{27} \mathrm{~N}_{2} \mathrm{O}_{7}[\mathrm{M}+\mathrm{H}]^{+}$: 467.1818; Found: 467.1611.

2.15. Experimental Procedure for the Preparation of (3-(2,5-Dimethoxyphenyl)isoxazol-5-yl)methanol (15a). To a solution of compound $7 \mathbf{a}(2 \mathrm{~g}, 11.11 \mathrm{mmol})$ in ethyl acetate $(20 \mathrm{~mL})$, compound $14(2.01 \mathrm{~g}, 16.66 \mathrm{mmol}), \mathrm{N}$-chlorosuccinamide $(2.21 \mathrm{~g}, 16.66 \mathrm{mmol})$, and $\mathrm{NaHCO}_{3}(1.86 \mathrm{~g}, 22.22 \mathrm{mmol})$ were added and the reaction mixture was refluxed for $16 \mathrm{~h}$. The 
progress of the reaction was monitored by TLC analysis $(30 \%$ ethyl acetate/pet ether). Then, water $(20 \mathrm{~mL})$ was added and the reaction mixture was extracted with ethyl acetate. The combined organic layer was washed with water, brined, and dried over anhydrous $\mathrm{Na}_{2} \mathrm{SO}_{4}$. Evaporation of the solvent gave the crude product which was purified by column chromatography to give the compound 15 a $(2.1 \mathrm{~g}, 80 \%$ yield) as white solid.

m.p. 69-73 ${ }^{\circ} \mathrm{C} . \mathrm{IR}\left(\mathrm{KBr}, \mathrm{cm}^{-1}\right): 3330,2943,1709,1510,1295$, 1225, 1036. ${ }^{1} \mathrm{H}$ NMR $\left(400 \mathrm{MHz}, \mathrm{CDCl}_{3}\right): \delta=7.45(\mathrm{~d}, J=$ $2.9 \mathrm{~Hz}, 1 \mathrm{H}), 7.01-6.90(\mathrm{~m}, 2 \mathrm{H}), 6.79(\mathrm{~s}, 1 \mathrm{H}), 4.82(\mathrm{~d}, J=6.3 \mathrm{~Hz}$, $2 \mathrm{H}), 3.83(\mathrm{~d}, J=12.0 \mathrm{~Hz}, 6 \mathrm{H}), 2.19(\mathrm{t}, J=6.5 \mathrm{~Hz}, 1 \mathrm{H})$. MS (EI): $m / z 235(\mathrm{M}+1,100)$.

2.16. Experimental Procedure for the Preparation of (3-(2, 5-Dimethoxy-4-methylphenyl)isoxazol-5-yl)methanol (15b). To a solution of compound $7 \mathbf{b}(1.0 \mathrm{~g}, 5.12 \mathrm{mmol})$ in ethyl acetate $(20 \mathrm{~mL})$, compound $\mathbf{1 4}(0.93 \mathrm{~g}, 7.69 \mathrm{mmol}), \mathrm{N}$-chlorosuccinamide $(1.02 \mathrm{~g}, 7.69 \mathrm{mmol})$, and $\mathrm{NaHCO}_{3}(0.861 \mathrm{~g}$, $10.2 \mathrm{mmol}$ ) were added and refluxed for $16 \mathrm{hr}$. The progress of the reaction was monitored by TLC analysis (30\% Ethyl acetate/pet ether). Then, water $(20 \mathrm{~mL})$ was added and the reaction mixture was extracted with ethyl acetate. The combined organic layer was washed with water, brined, and dried over anhydrous $\mathrm{Na}_{2} \mathrm{SO}_{4}$. Evaporation of the solvent gave the crude product which was purified by column chromatography to give the compound $\mathbf{1 5 b}$ ( $1.0 \mathrm{~g}, 90 \%$ yield) as off-white solid.

m.p. 58-62 ${ }^{\circ}$ C. IR $\left(\mathrm{KBr}, \mathrm{cm}^{-1}\right): 3426,2940,2129,1715,1216$, 1038. ${ }^{1} \mathrm{H}$ NMR (300 MHz, DMSO): $\delta=11.05(\mathrm{~s}, 1 \mathrm{H}), 7.27(\mathrm{~s}$, $1 \mathrm{H}), 7.05(\mathrm{~s}, 1 \mathrm{H}), 6.74(\mathrm{~s}, 1 \mathrm{H}), 4.60(\mathrm{~d}, J=0.8 \mathrm{~Hz}, 2 \mathrm{H}), 3.80(\mathrm{~d}$, $J=10.2 \mathrm{~Hz}, 6 \mathrm{H}), 2.21(\mathrm{~s}, 3 \mathrm{H})$. MS (EI): $m / z 250(\mathrm{M}+1,100)$.

2.17. Experimental Procedure for the Preparation of 5(Bromomethyl)-3-(2,5-dimethoxyphenyl)isoxazole (16a). To a solution of compound $15 \mathrm{a}(1.5 \mathrm{~g}, 6.38 \mathrm{mmol})$ in dichloromethane $(15 \mathrm{~mL})$, phosphorous tribromide $(2.59 \mathrm{~g}$, $9.57 \mathrm{mmol}$ ) was added at $0^{\circ} \mathrm{C}$ under nitrogen atmosphere. Then the reaction mixture was stirred at RT for $16 \mathrm{hr}$. The progress of the reaction was monitored by TLC analysis (30\% ethyl acetate/pet ether). Then, water $(10 \mathrm{~mL})$ was added and the reaction mixture was extracted with dichloromethane. The combined organic layer was washed with water, brined, and dried over anhydrous $\mathrm{Na}_{2} \mathrm{SO}_{4}$. The solvent was evaporated and the crude reaction mixture was purified by column chromatography to give the compound 16a (1.2 $\mathrm{g}$, 63\% yield) as white solid.

m.p. $71-75^{\circ} \mathrm{C}$. IR $\left(\mathrm{KBr}, \mathrm{cm}^{-1}\right): 3432,2925,1852,1603,1465$, 1270, 1021. ${ }^{1} \mathrm{H} \mathrm{NMR}\left(400 \mathrm{MHz}, \mathrm{CDCl}_{3}\right): \delta=7.47(\mathrm{~d}, J=3.0 \mathrm{~Hz}$, $1 \mathrm{H}), 7.02-6.91(\mathrm{~m}, 2 \mathrm{H}), 6.87(\mathrm{~s}, 1 \mathrm{H}), 4.52(\mathrm{~s}, 2 \mathrm{H}), 3.84(\mathrm{~d}, J=$ $15.1 \mathrm{~Hz}, 6 \mathrm{H})$. MS (EI): $m / z 297(\mathrm{M}+1,100)$.

2.18. Experimental Procedure for the Preparation of 5(Bromomethyl)-3-(2,5-dimethoxy-4-methylphenyl)isoxazole (16b). To a solution of compound $\mathbf{1 5 b}(1.0 \mathrm{~g}, 4.0 \mathrm{mmol})$ in dichloromethane $(20 \mathrm{~mL})$, phosphorous tribromide $(1.62 \mathrm{~g}$, $6.0 \mathrm{mmol}$ ) was added at $0^{\circ} \mathrm{C}$ under nitrogen atmosphere. Then the reaction mixture was stirred at $\mathrm{RT}$ for $16 \mathrm{hr}$. The progress of the reaction was monitored by TLC analysis (30\% ethyl acetate/pet ether). Then, water $(20 \mathrm{~mL})$ was added and the reaction mixture was extracted with dichloromethane. The combined organic layer was washed with water, brined, and dried over anhydrous $\mathrm{Na}_{2} \mathrm{SO}_{4}$. The solvent was evaporated and the crude reaction mixture was purified by column chromatography to give the compound $16 \mathbf{b}(1.0 \mathrm{~g}$, $80 \%$ yield) as brown solid.

m.p. 65-68 C. IR (KBr, cm $\left.{ }^{-1}\right): 3445,2936,1716,1471,1285$, $1218,1042 .{ }^{1} \mathrm{H}$ NMR $\left(400 \mathrm{MHz}, \mathrm{CDCl}_{3}\right): \delta=7.39$ (s, 1H), 6.82 $(\mathrm{d}, J=6.4 \mathrm{~Hz}, 2 \mathrm{H}), 4.82(\mathrm{dd}, J=6.5 \mathrm{~Hz}, 2 \mathrm{H}), 3.85(\mathrm{~s}, 6 \mathrm{H}), 2.27$ (s, 3H). MS (EI): $m / z 311(\mathrm{M}+1,100)$.

2.19. Experimental Procedure for the Preparation of Methyl 3(3-(2,5-Dimethoxyphenyl)isoxazol-5-yl)-2-((diphenylmethylene)amino)propanoate (17a). To a solution of compound $\mathbf{1 0}$ $(1.12 \mathrm{~g}, 4.44 \mathrm{mmol})$ in acetonitrile $(20 \mathrm{~mL}), \mathrm{K}_{2} \mathrm{CO}_{3}(2.78 \mathrm{~g}$, $20.2 \mathrm{mmol}$ ) was added under nitrogen atmosphere and stirred at RT for $1 \mathrm{hr}$. Then compound 16a (1.2 g, $4.04 \mathrm{mmol})$ was added and the reaction mixture was refluxed for $16 \mathrm{hr}$. The progress of the reaction was monitored by TLC analysis (20\% ethyl acetate/pet ether). Then, reaction mixture was filtered and filtrate was evaporated. The crude reaction mixture was purified by column chromatography to give the compound 17a (1.5 g, 74\% yield) as light yellow liquid.

IR $\left(\mathrm{KBr}, \mathrm{cm}^{-1}\right): 3292,2952,1740,1510,1276,1227,1043 .{ }^{1} \mathrm{H}$ $\operatorname{NMR}\left(300 \mathrm{MHz}, \mathrm{CDCl}_{3}\right): \delta=7.63(\mathrm{~d}, J=6.9 \mathrm{~Hz}, 2 \mathrm{H}), 7.44-$ $7.28(\mathrm{~m}, 7 \mathrm{H}), 7.04-6.83(\mathrm{~m}, 4 \mathrm{H}), 6.52(\mathrm{~s}, 1 \mathrm{H}), 4.47(\mathrm{dd}, J=7.5$, $5.8 \mathrm{~Hz}, 1 \mathrm{H}), 3.78(\mathrm{~d}, J=8.5 \mathrm{~Hz}, 6 \mathrm{H}), 3.59(\mathrm{~s}, 3 \mathrm{H}), 3.53-3.41(\mathrm{~m}$, 2H). MS (EI): $m / z 470(\mathrm{M}+1,100)$.

2.20. Experimental Procedure for the Preparation of Methyl 3-(3-(2,5-Dimethoxy-4-methylphenyl)isoxazol-5-yl)-2-((diphenylmethylene)amino)propanoate (17b). To a solution of compound $10(0.9 \mathrm{~g}, 3.55 \mathrm{mmol})$ in acetonitrile $(20 \mathrm{~mL})$, $\mathrm{K}_{2} \mathrm{CO}_{3}(2.45 \mathrm{~g}, 17.7 \mathrm{mmol})$ was added under nitrogen atmosphere and stirred at RT for $1 \mathrm{hr}$. Then compound 16b $(1.21 \mathrm{~g}, 3.91 \mathrm{mmol})$ was added and the reaction mixture was refluxed for $16 \mathrm{hr}$. The progress of the reaction was monitored by TLC analysis (20\% ethyl acetate/pet ether). Then, reaction mixture was filtered and filtrate was evaporated. The crude reaction mixture was purified by column chromatography to give the compound $\mathbf{1 7 b}(1.1 \mathrm{~g}, 69 \%$ yield) as off-white solid.

m.p. $142-146^{\circ} \mathrm{C}$. IR $\left(\mathrm{KBr}, \mathrm{cm}^{-1}\right): 3447,2949,1736,1284$, 1213, 1041. ${ }^{1} \mathrm{H}$ NMR $\left(300 \mathrm{MHz} \mathrm{CDCl}_{3}\right): \delta=7.63(\mathrm{~d}, J=8.2 \mathrm{~Hz}$, 2H), 7.49-7.24 (m, 7H), 7.04-6.92 (m, 2H), 6.75 (s, 1H), 6.53 (s, $1 \mathrm{H}), 4.61-4.36(\mathrm{~m}, 1 \mathrm{H}), 3.79(\mathrm{dd}, J=16.5 \mathrm{~Hz}, 6 \mathrm{H}), 3.59$ (d, $J=0.9 \mathrm{~Hz}, 3 \mathrm{H}), 3.54-3.35(\mathrm{~m}, 2 \mathrm{H}), 2.24$ (s, 3H). MS (EI): $\mathrm{m} / z$ $484(\mathrm{M}+1,100)$.

2.21. Experimental Procedure for the Preparation of Methyl 2Amino-3-(3-(2,5-dimethoxyphenyl)isoxazol-5-yl)propanoate (18a). To a solution of compound $17 \mathrm{a}(1.5 \mathrm{~g}, 3.19 \mathrm{mmol})$ in diethyl ether $(20 \mathrm{~mL}), 1 \mathrm{M} \mathrm{HCl}(20 \mathrm{~mL})$ was added at $0^{\circ} \mathrm{C}$. Then the reaction mixture was stirred at RT for $16 \mathrm{hr}$. The progress of the reaction was monitored by TLC analysis (10\% methanol/chloroform). The layers were separated and the aqueous layer was basified with aqueous ammonia 
until PH 10 and extracted with ethyl acetate. The combined organic layers were washed with water, brined, and dried over anhydrous $\mathrm{Na}_{2} \mathrm{SO}_{4}$. Evaporation of the solvent gave the compound $18 \mathrm{a}$ ( $0.850 \mathrm{~g}, 87 \%$ yield) as pale yellow liquid.

$\operatorname{IR}\left(\mathrm{KBr}, \mathrm{cm}^{-1}\right): 3383,2953,1738,1602,1471,1227,1042 .{ }^{1} \mathrm{H}$ NMR (300 MHz, DMSO): $\delta=7.27(\mathrm{~d}, J=3.0 \mathrm{~Hz}, 1 \mathrm{H}), 7.17-$ $6.97(\mathrm{~m}, 2 \mathrm{H}), 6.67(\mathrm{~s}, 1 \mathrm{H}), 3.78(\mathrm{~d}, J=17.1 \mathrm{~Hz}, 7 \mathrm{H}), 3.64(\mathrm{~s}$, $3 \mathrm{H}), 3.07$ (qd, $J=15.1,6.6 \mathrm{~Hz}, 2 \mathrm{H}), 1.99$ (s, 2H). MS (EI): $\mathrm{m} / z$ $306(\mathrm{M}+1,100)$.

2.22. Experimental Procedure for the Preparation of Methyl 2-Amino-3-(3-(2,5-dimethoxy-4-methylphenyl)isoxazol-5-yl) propanoate $(\mathbf{1 8 b})$. To a solution of compound $\mathbf{1 7 b}(0.5 \mathrm{~g}$, $1.03 \mathrm{mmol})$ in diethyl ether $(10 \mathrm{~mL}), 1 \mathrm{M} \mathrm{HCl}(10 \mathrm{~mL})$ was added at $0^{\circ} \mathrm{C}$. Then the reaction mixture was stirred at RT for $16 \mathrm{hr}$. The progress of the reaction was monitored by TLC analysis (10\% methanol/chloroform). The layers were separated and the aqueous layer was basified with aqueous ammonia until PH 10 and extracted with ethyl acetate. The combined organic layer was washed with water, brined, and dried over anhydrous $\mathrm{Na}_{2} \mathrm{SO}_{4}$. Evaporation of the solvent gave the compound $18 \mathrm{~b}(0.27 \mathrm{~g}, 82 \%$ yield $)$ as off-white solid.

m.p. $218-221^{\circ} \mathrm{C}$. IR $\left(\mathrm{KBr}, \mathrm{cm}^{-1}\right): 3468,2838,1741,1472$, $1250,1220,1041 .{ }^{1} \mathrm{H}$ NMR $(300 \mathrm{MHz}, \mathrm{DMSO}): \delta=8.58(\mathrm{~s}$, $2 \mathrm{H}), 7.28(\mathrm{~s}, 1 \mathrm{H}), 7.06(\mathrm{~s}, 1 \mathrm{H}), 6.82(\mathrm{~s}, 1 \mathrm{H}), 4.53(\mathrm{t}, J=6.1 \mathrm{~Hz}$, $1 \mathrm{H}), 3.93-3.65(\mathrm{~m}, 9 \mathrm{H}), 3.41(\mathrm{~d}, J=6.2 \mathrm{~Hz}, 2 \mathrm{H}), 2.22(\mathrm{~s}, 3 \mathrm{H})$. MS (EI): $m / z 320(\mathrm{M}+1,100)$.

2.23. Experimental Procedure for the Preparation of Methyl 2-((tert-Butoxycarbonyl)amino)-3-(3-(2,5-dimethoxyphenyl) isoxazol-5-yl)propanoate (19a). To a solution of compound 18a $(0.300 \mathrm{~g}, 0.98 \mathrm{mmol})$ in dichloromethane $(15 \mathrm{~mL})$, triethylamine $(0.19 \mathrm{~g}, 1.98 \mathrm{mmol})$ was added. Then $(\mathrm{Boc})_{2} \mathrm{O}$ $(0.23 \mathrm{~g}, 1.07 \mathrm{mmol})$ was added and the reaction mixture was stirred at RT for $16 \mathrm{hr}$. The progress of the reaction was monitored by TLC analysis (30\% ethyl acetate/pet ether). Then, water $(10 \mathrm{~mL})$ was added and the reaction mixture was extracted with dichloromethane. The combined organic layer was washed with water, brined, and dried over anhydrous $\mathrm{Na}_{2} \mathrm{SO}_{4}$. Evaporation of the solvent gave the crude compound which was purified by column chromatography to give the compound $19 \mathrm{a}(0.380 \mathrm{~g}, 95 \%$ yield $)$ as light brown solid.

m.p. $110-113^{\circ} \mathrm{C}$. IR $\left(\mathrm{KBr}, \mathrm{cm}^{-1}\right)$ : $3372,2948,1742,1690$, $1524,1274,1220,1025 .{ }^{1} \mathrm{H}$ NMR $\left(300 \mathrm{MHz}, \mathrm{CDCl}_{3}\right): \delta=7.44$ $(\mathrm{d}, J=2.8 \mathrm{~Hz}, 1 \mathrm{H}), 7.01-6.88(\mathrm{~m}, 2 \mathrm{H}), 6.62(\mathrm{~s}, 1 \mathrm{H}), 5.24(\mathrm{~s}, 1 \mathrm{H})$, $4.70(\mathrm{~s}, 1 \mathrm{H}), 3.90-3.72(\mathrm{~m}, 9 \mathrm{H}), 3.37(\mathrm{~d}, J=6.0 \mathrm{~Hz}, 2 \mathrm{H}), 1.44(\mathrm{~s}$, $9 \mathrm{H}) .{ }^{13} \mathrm{C}$ NMR $\left(100 \mathrm{MHz}, \mathrm{CDCl}_{3}\right): \delta_{\mathrm{C}} 171.2,167.4,159.9,155.0$, $153.6,151.5,118.2,117.3,113.4,113.0,104.5,80.2,56.1,55.8,52.6$, 52.1, 29.7, 28.2. MS (EI): $m / z 406(\mathrm{M}+1,100)$. HRMS (ESI) Calcd for $\mathrm{C}_{20} \mathrm{H}_{26} \mathrm{~N}_{2} \mathrm{O}_{7}[\mathrm{M}+\mathrm{H}]^{+}$: 407.1818; Found: 407.1743 .

2.24. Experimental Procedure for the Preparation of Methyl 3(3-(2,5-Dimethoxyphenyl)isoxazol-5-yl)-2-pivalamidopropanoate $(\mathbf{1 9 b})$. To a solution of compound 18a $(0.300 \mathrm{~g}$, $0.98 \mathrm{mmol})$ in DCM $(15 \mathrm{~mL})$, dimethylaminopyridine $(0.012 \mathrm{~g}, 0.098 \mathrm{mmol})$ was added. Then pivaloyl chloride $(0.356 \mathrm{~g}, 2.94 \mathrm{mmol})$ was added and the reaction mixture was stirred at RT for $16 \mathrm{hr}$. The progress of the reaction was monitored by TLC analysis (30\% ethyl acetate/pet ether). Then, water $(10 \mathrm{~mL})$ was added and the reaction mixture was extracted with dichloromethane. The combined organic layer was washed with water, brined, and dried over anhydrous $\mathrm{Na}_{2} \mathrm{SO}_{4}$. Evaporation of the solvent gave the crude compound which was purified by column chromatography to give the compound $19 \mathbf{b}(0.300 \mathrm{~g}, 78 \%$ yield $)$ as light yellow liquid.

IR $\left(\mathrm{KBr}, \mathrm{cm}^{-1}\right): 3366,2959,1745,1651,1511,1267,1227$, 1043. ${ }^{1} \mathrm{H}$ NMR $\left(300 \mathrm{MHz}, \mathrm{CDCl}_{3}\right): \delta=7.44(\mathrm{~d}, J=2.8 \mathrm{~Hz}$, $1 \mathrm{H}), 7.03-6.85(\mathrm{~m}, 2 \mathrm{H}), 6.59(\mathrm{~d}, J=2.3 \mathrm{~Hz}, 1 \mathrm{H}), 6.38(\mathrm{~d}, J=$ $7.0 \mathrm{~Hz}, 1 \mathrm{H}), 5.00-4.80(\mathrm{~m}, 1 \mathrm{H}), 3.95-3.70(\mathrm{~m}, 9 \mathrm{H}), 3.56-3.28$ $(\mathrm{m}, 2 \mathrm{H}), 1.22(\mathrm{~d}, J=2.3 \mathrm{~Hz}, 9 \mathrm{H}) .{ }^{13} \mathrm{C} \mathrm{NMR}\left(100 \mathrm{MHz}, \mathrm{CDCl}_{3}\right)$ : $\delta_{\mathrm{C}} 178.2,171.1,167.3,159.9,153.6,151.5,118.1,117.4,113.3,112.9$, 104.7, 56.0, 55.8, 52.8, 50.8, 38.6, 28.9, 27.3, 27.0. MS (EI): $\mathrm{m} / z$ $390(\mathrm{M}+1,100)$.

2.25. Experimental Procedure for the Preparation of Methyl 2((tert-Butoxycarbonyl)amino)-3-(3-(2,5-dimethoxy-4-methylphenyl)isoxazol-5-yl)propanoate (19c). To a solution of compound $18 \mathrm{~b}(0.2 \mathrm{~g}, 0.62 \mathrm{mmol})$ in dichloromethane $(10 \mathrm{~mL})$, triethyl amine $(0.12 \mathrm{~g}, 1.25 \mathrm{mmol})$ was added. Then $(\mathrm{Boc})_{2} \mathrm{O}(0.15 \mathrm{~g}, 0.68 \mathrm{mmol})$ was added and the reaction mixture was stirred at RT for $16 \mathrm{hr}$. The progress of the reaction was monitored by TLC analysis (30\% ethyl acetate/pet ether). Then, water $(10 \mathrm{~mL})$ was added and the reaction mixture was extracted with dichloromethane. The combined organic layer was washed with water, brined, and dried over anhydrous $\mathrm{Na}_{2} \mathrm{SO}_{4}$. Evaporation of the solvent gave the crude compound which was purified by column chromatography to give the compound 19c $(0.25 \mathrm{~g}, 95 \%$ yield) as off-white solid.

m.p. $103-107^{\circ} \mathrm{C}$. IR $\left(\mathrm{KBr}, \mathrm{cm}^{-1}\right): 3344,2928,2846,1733$, $1677,1526,1219,1048 .{ }^{1} \mathrm{H}$ NMR (300 MHz, DMSO): $\delta=7.47$ $(\mathrm{d}, J=8.3 \mathrm{~Hz}, 1 \mathrm{H}), 7.26(\mathrm{~s}, 1 \mathrm{H}), 7.04(\mathrm{~s}, 1 \mathrm{H}), 6.68(\mathrm{~d}, J=$ $4.3 \mathrm{~Hz}, 1 \mathrm{H}), 4.39$ (t, $J=9.2 \mathrm{~Hz}, 1 \mathrm{H}), 3.91-3.73(\mathrm{~m}, 6 \mathrm{H}), 3.65$ $(\mathrm{d}, J=10.3 \mathrm{~Hz}, 3 \mathrm{H}), 3.28-3.04(\mathrm{~m}, 2 \mathrm{H}), 2.21(\mathrm{~s}, 3 \mathrm{H}), 1.35$ (s, $9 \mathrm{H}) .{ }^{13} \mathrm{C}$ NMR $\left(100 \mathrm{MHz}\right.$, DMSO-d $\left.{ }_{6}\right): \delta_{\mathrm{C}} 171.9,168.7,159.2$, 155.2, 151.2, 150.7, 129.3, 115.3, 114.6, 109.6, 109.5, 103.6, 78.5, 56.1, 55.5, 52.1, 51.9, 28.0, 26.8, 16.2. MS (EI): $m / z 420$ (M + 1, 100). HRMS (ESI) Calcd for $\mathrm{C}_{21} \mathrm{H}_{29} \mathrm{~N}_{2} \mathrm{O}_{7}[\mathrm{M}+\mathrm{H}]^{+}$: 421.1975; Found: 421.1988.

2.26. Experimental Procedure for the Preparation of Methyl 3-(3-(2,5-Dimethoxy-4-methylphenyl)isoxazol-5-yl)-2-pivalamidopropanoate $(\mathbf{1 9 d})$. To a solution of compound $\mathbf{1 8 b}$ $(0.3 \mathrm{~g}, 0.93 \mathrm{mmol})$ in dichloromethane $(10 \mathrm{~mL})$, dimethylaminopyridine $(0.011 \mathrm{~g}, 0.093 \mathrm{mmol})$ was added. Then pivaloyl chloride $(0.34 \mathrm{~g}, 2.81 \mathrm{mmol})$ was added and the reaction mixture was stirred at RT for $16 \mathrm{hr}$. The progress of the reaction was monitored by TLC analysis (30\% ethyl acetate/pet ether). Then, water $(10 \mathrm{~mL})$ was added and the reaction mixture was extracted with dichloromethane. The combined organic layer was washed with water, brined, and dried over anhydrous $\mathrm{Na}_{2} \mathrm{SO}_{4}$. Evaporation of the solvent gave the crude compound which was purified by column 
chromatography to give the compound 19d ( $0.31 \mathrm{~g}, 82 \%$ yield) as off-white solid.

m.p. $116-120^{\circ} \mathrm{C}$. IR $\left(\mathrm{KBr}, \mathrm{cm}^{-1}\right): 3323,2963,1741,1531$, 1431, 1217, 1041. ${ }^{1} \mathrm{H}$ NMR (300 MHz, DMSO): $\delta=7.98$ (d, $J=8.0 \mathrm{~Hz}, 1 \mathrm{H}), 7.25(\mathrm{~s}, 1 \mathrm{H}), 7.03(\mathrm{~s}, 1 \mathrm{H}), 6.65(\mathrm{~s}, 1 \mathrm{H}), 4.61$ $(\mathrm{td}, J=8.2,6.6 \mathrm{~Hz}, 1 \mathrm{H}), 3.78(\mathrm{~d}, J=5.9 \mathrm{~Hz}, 6 \mathrm{H}), 3.66(\mathrm{~s}$, $3 \mathrm{H}), 3.38-3.24(\mathrm{~m}, 2 \mathrm{H}), 2.21(\mathrm{~s}, 3 \mathrm{H}), 1.07(\mathrm{~s}, 9 \mathrm{H}) .{ }^{13} \mathrm{C} \mathrm{NMR}$ $\left(100 \mathrm{MHz}, \mathrm{DMSO}-\mathrm{d}_{6}\right): \delta_{\mathrm{C}} 177.5,171.2,169.0,159.2,151.2,150.7$, $129.2,115.3,114.7,109.6,103.6,56.0,55.5,52.1,50.4,37.8,27.5$, 27.0, 16.2. MS (EI): $m / z 404(\mathrm{M}+1,100)$. HRMS (ESI): Calcd for $\mathrm{C}_{21} \mathrm{H}_{29} \mathrm{~N}_{2} \mathrm{O}_{6}[\mathrm{M}+\mathrm{H}]^{+}$: 405.2026; Found: 405.1703.

2.27. Experimental Procedure for the Preparation of Methyl 2-((tert-Butoxycarbonyl)amino)-3-(3-(3,6-dioxocyclohexa-

1,4-dien-1-yl)isoxazol-5-yl)propanoate (20a). To a solution of compound 19a $(0.250 \mathrm{~g}, 0.61 \mathrm{mmol})$ in acetonitrile $(10 \mathrm{~mL})$ and $\mathrm{H}_{2} \mathrm{O}(2 \mathrm{~mL})$, CAN $(1.01 \mathrm{~g}, 1.84 \mathrm{mmol})$ was added and the reaction mixture was stirred at RT for $1 \mathrm{~h}$. The progress of the reaction was monitored by TLC analysis ( $20 \%$ ethyl acetate/Pet ether). Then, water $(10 \mathrm{~mL})$ was added and extracted with ethyl acetate. The combined organic layer was washed with water, brined, and dried over anhydrous $\mathrm{Na}_{2} \mathrm{SO}_{4}$. Evaporation of the solvent in high vacuum gave the compound 20a $(0.150 \mathrm{~g}, 64 \%$ yield $)$ as yellow solid.

m.p. $110-112^{\circ} \mathrm{C}$. IR $\left(\mathrm{KBr}, \mathrm{cm}^{-1}\right)$ : $3359,2979,2955,1749$, $1688,1524,1283,1163 .{ }^{1} \mathrm{H}$ NMR $\left(300 \mathrm{MHz}, \mathrm{CDCl}_{3}\right): \delta=7.44-$ $7.36(\mathrm{~m}, 1 \mathrm{H}), 6.87(\mathrm{~d}, J=1.5 \mathrm{~Hz}, 2 \mathrm{H}), 6.69(\mathrm{~s}, 1 \mathrm{H}), 5.22(\mathrm{~s}, 1 \mathrm{H})$, $4.68(\mathrm{~s}, 1 \mathrm{H}), 3.80(\mathrm{~s}, 3 \mathrm{H}), 3.53-3.25(\mathrm{~m}, 2 \mathrm{H}), 1.44(\mathrm{~s}, 9 \mathrm{H}) .{ }^{13} \mathrm{C}$ NMR $\left(100 \mathrm{MHz}, \mathrm{CDCl}_{3}\right): \delta_{\mathrm{C}} 186.7,185.0,170.9,169.3,156.1$, 154.9, 136.7, 136.5, 134.4, 133.3, 104.4, 80.4, 52.8, 52.0, 29.8, 28.2. MS (EI): $m / z 376(\mathrm{M}+1,100)$. HRMS (ESI): Calcd for $\mathrm{C}_{18} \mathrm{H}_{20} \mathrm{~N}_{2} \mathrm{O}_{7}[\mathrm{M}+\mathrm{H}]^{+}$: 377.1349; Found: 377.0531 .

2.28. Experimental Procedure for the Preparation of Methyl 3-(3-(3,6-Dioxocyclohexa-1,4-dien-1-yl)isoxazol-5-yl)-2-pivalamidopropanoate $(\mathbf{2 0 b})$. To a solution of compound $\mathbf{1 9 b}$ $(0.2 \mathrm{~g}, 0.51 \mathrm{mmol})$ in acetonitrile $(10 \mathrm{~mL})$ and $\mathrm{H}_{2} \mathrm{O}(2 \mathrm{~mL})$, CAN $(0.560 \mathrm{~g}, 1.025 \mathrm{mmol})$ was added and the reaction mixture was stirred at RT for $1 \mathrm{~h}$. The progress of the reaction was monitored by TLC analysis (30\% ethyl acetate/pet ether). Then, water $(10 \mathrm{~mL})$ was added and extracted with ethyl acetate. The combined organic layer was washed with water, brined, and dried over anhydrous $\mathrm{Na}_{2} \mathrm{SO}_{4}$. Evaporation of the solvent in high vacuum gave the compound $20 \mathrm{~b}(0.160 \mathrm{~g}$, $86 \%$ yield) as yellow solid.

m.p. $107-109^{\circ} \mathrm{C}$. IR $\left(\mathrm{KBr}, \mathrm{cm}^{-1}\right)$ : 3312, 2961, 2872, 1752, $1662,1639,1534,1287,1206,1093 .{ }^{1} \mathrm{H}$ NMR $(400 \mathrm{MHz}$, $\left.\mathrm{CDCl}_{3}\right): \delta=7.39(\mathrm{~s}, 1 \mathrm{H}), 6.87(\mathrm{~s}, 2 \mathrm{H}), 6.65(\mathrm{~s}, 1 \mathrm{H}), 6.36(\mathrm{~d}$, $J=7.1 \mathrm{~Hz}, 1 \mathrm{H}), 4.90(\mathrm{q}, J=5.7 \mathrm{~Hz}, 1 \mathrm{H}), 3.82(\mathrm{~s}, 3 \mathrm{H}), 3.53$ $(\mathrm{dd}, J=15.4,5.4 \mathrm{~Hz}, 1 \mathrm{H}), 3.37(\mathrm{dd}, J=15.3,5.3 \mathrm{~Hz}, 1 \mathrm{H}), 1.22$ (s, 9H). ${ }^{13} \mathrm{C}$ NMR $\left(100 \mathrm{MHz}, \mathrm{CDCl}_{3}\right): \delta_{\mathrm{C}} 186.7,184.9,178.2$, $170.9,169.2,156.0,136.7,136.5,134.3,133.3,104.5,52.9,50.8$, 38.7, 29.0, 27.3. MS (EI): $m / z 360(\mathrm{M}+1,100)$. HRMS (ESI): Calcd for $\mathrm{C}_{18} \mathrm{H}_{21} \mathrm{~N}_{2} \mathrm{O}_{6}[\mathrm{M}+\mathrm{H}]^{+}$: 361.1400; Found: 361.1388 .

2.29. Experimental Procedure for the Preparation of Methyl 2-((tert-Butoxycarbonyl)amino)-3-(3-(4-methyl-3,6-dioxocyclohexa-1,4-dien-1-yl)isoxazol-5-yl)propanoate (20c). To a solution of compound $19 \mathrm{c}(0.2 \mathrm{~g}, 0.47 \mathrm{mmol})$ in acetonitrile $(10 \mathrm{~mL})$ and $\mathrm{H}_{2} \mathrm{O}(2 \mathrm{~mL})$, CAN $(0.52 \mathrm{~g}, 0.95 \mathrm{mmol})$ was added and the reaction mixture was stirred at RT for $1 \mathrm{~h}$. The progress of the reaction was monitored by TLC analysis (30\% ethyl acetate/pet ether). Then, water $(10 \mathrm{~mL})$ was added and extracted with ethyl acetate. The combined organic layer was washed with water, brined, and dried over anhydrous $\mathrm{Na}_{2} \mathrm{SO}_{4}$. Evaporation of the solvent in high vacuum gave the compound $20 \mathrm{c}(0.185 \mathrm{~g}, 86 \%$ yield) as yellow solid.

m.p. $89-93^{\circ} \mathrm{C}$. IR $\left(\mathrm{KBr}, \mathrm{cm}^{-1}\right): 3379,2977,1742,1695,1654$, $1524,1239,1170,1040 .{ }^{1} \mathrm{H}$ NMR $\left(300 \mathrm{MHz}, \mathrm{CDCl}_{3}\right): \delta=7.36$ (s, $1 \mathrm{H}), 6.74-6.62(\mathrm{~m}, 2 \mathrm{H}), 5.23(\mathrm{~d}, J=6.3 \mathrm{~Hz}, 1 \mathrm{H}), 4.68(\mathrm{~s}$, $1 \mathrm{H}), 3.80(\mathrm{~s}, 3 \mathrm{H}), 3.39(\mathrm{~m}, 2 \mathrm{H}), 2.25-1.99(\mathrm{~m}, 3 \mathrm{H}), 1.44(\mathrm{~s}$, 9H) ${ }^{13} \mathrm{C}$ NMR $\left(100 \mathrm{MHz}, \mathrm{CDCl}_{3}\right): \delta_{\mathrm{C}} 187.3,185.2,170.9,169.1$, $156.1,154.9,146.2,134.2,133.5,133.4,109.9,104.5,52.8,52.0$, 29.8, 28.2, 15.5. MS (EI): $m / z 390(\mathrm{M}+1,100)$. HRMS (ESI): Calcd for $\mathrm{C}_{19} \mathrm{H}_{23} \mathrm{~N}_{2} \mathrm{O}_{7}[\mathrm{M}+\mathrm{H}]^{+}$: 391.1505; Found: 391.1601.

2.30. Experimental Procedure for the Preparation of Methyl 3(3-(4-Methyl-3,6-dioxocyclohexa-1,4-dien-1-yl)isoxazol-5-yl)2-pivalamidopropanoate (20d). To a solution of compound 19d $(0.2 \mathrm{~g}, 0.49 \mathrm{mmol})$ in acetonitrile $(10 \mathrm{~mL})$ and $\mathrm{H}_{2} \mathrm{O}$ $(2 \mathrm{~mL}), \mathrm{CAN}(0.54 \mathrm{~g}, 0.99 \mathrm{mmol})$ was added and the reaction mixture was stirred at RT for $1 \mathrm{~h}$. The progress of the reaction was monitored by TLC analysis (30\% ethyl acetate/pet ether). After completion of the reaction, water $(10 \mathrm{~mL})$ was added and extracted with ethyl acetate thrice. The organic layers were combined, washed with water, brined, and dried over anhydrous $\mathrm{Na}_{2} \mathrm{SO}_{4}$. Evaporation of the solvent in high vacuum gave the compound $20 \mathrm{~d}(0.175 \mathrm{~g}, 94 \%$ yield $)$ as yellow solid.

m.p. $118-120^{\circ} \mathrm{C}$. IR $\left(\mathrm{KBr}, \mathrm{cm}^{-1}\right)$ : 3351, 2958, 2872, 1735 , $1657,1524,1230,1042 .{ }^{1} \mathrm{H}$ NMR $\left(300 \mathrm{MHz}, \mathrm{CDCl}_{3}\right): \delta=7.36$ $(\mathrm{s}, 1 \mathrm{H}), 6.70(\mathrm{q}, J=1.6 \mathrm{~Hz}, 1 \mathrm{H}), 6.68(\mathrm{~s}, 1 \mathrm{H}), 6.35(\mathrm{~d}, J=7.3 \mathrm{~Hz}$, $1 \mathrm{H}), 4.89(\mathrm{dt}, J=7.2,5.2 \mathrm{~Hz}, 1 \mathrm{H}), 3.82(\mathrm{~s}, 3 \mathrm{H}), 3.59-3.44(\mathrm{~m}$, $1 \mathrm{H}), 3.36(\mathrm{dd}, J=15.2,5.2 \mathrm{~Hz}, 1 \mathrm{H}), 2.11(\mathrm{~d}, J=1.7 \mathrm{~Hz}, 3 \mathrm{H}), 1.21$ (s, 9H) ${ }^{13} \mathrm{C}$ NMR $\left(100 \mathrm{MHz}, \mathrm{CDCl}_{3}\right): \delta_{\mathrm{C}} 187.3,185.2,178.2$, $171.0,169.0,156.1,146.2,134.1,133.5,133.4,104.6,52.9,50.8$, 38.7, 29.0, 27.3, 15.5. MS (EI): $m / z 374(\mathrm{M}+1,100)$. HRMS (ESI): Calcd for $\mathrm{C}_{19} \mathrm{H}_{23} \mathrm{~N}_{2} \mathrm{O}_{6}[\mathrm{M}+\mathrm{H}]^{+}$: 375.1556; Found: 375.1468 .

\section{Results and Discussion}

Our proposed strategy was based on a simple and lucid cycloaddition reaction [42-45] of alkyne 5 with oxime 7 to prepare isoxazole-amino acid hybrids 8 (Scheme 1). The alkyne 5 was prepared in five steps using the protocol developed by O'Donnell et al. starting from $\mathrm{N}$ (diphenylmethylene) glycine methyl ester [46, 47] using appropriate benzyl or propargyl halides. Subsequent oxidation of the suitable placed methoxy group in the aromatic ring of compound $\mathbf{8}$ will provide isoxazole tethered quinoneamino acid hybrids 9 .

To start with, the compound $\mathbf{3} \mathbf{a}$ or $\mathbf{3 b}$ was prepared according to literature procedure [48] starting from 4bromobenzyl bromide. Then the compound $\mathbf{3 a}$ or $\mathbf{3 b}$ reacted with TMS-acetylene in the presence of $\mathrm{CuI} / \mathrm{Et}_{3} \mathrm{~N} /$ 
TABLE 1: The yields and purity of the novel isoxazole-phenyl alanine and isoxazole tethered quinone-phenyl alanine hybrids.

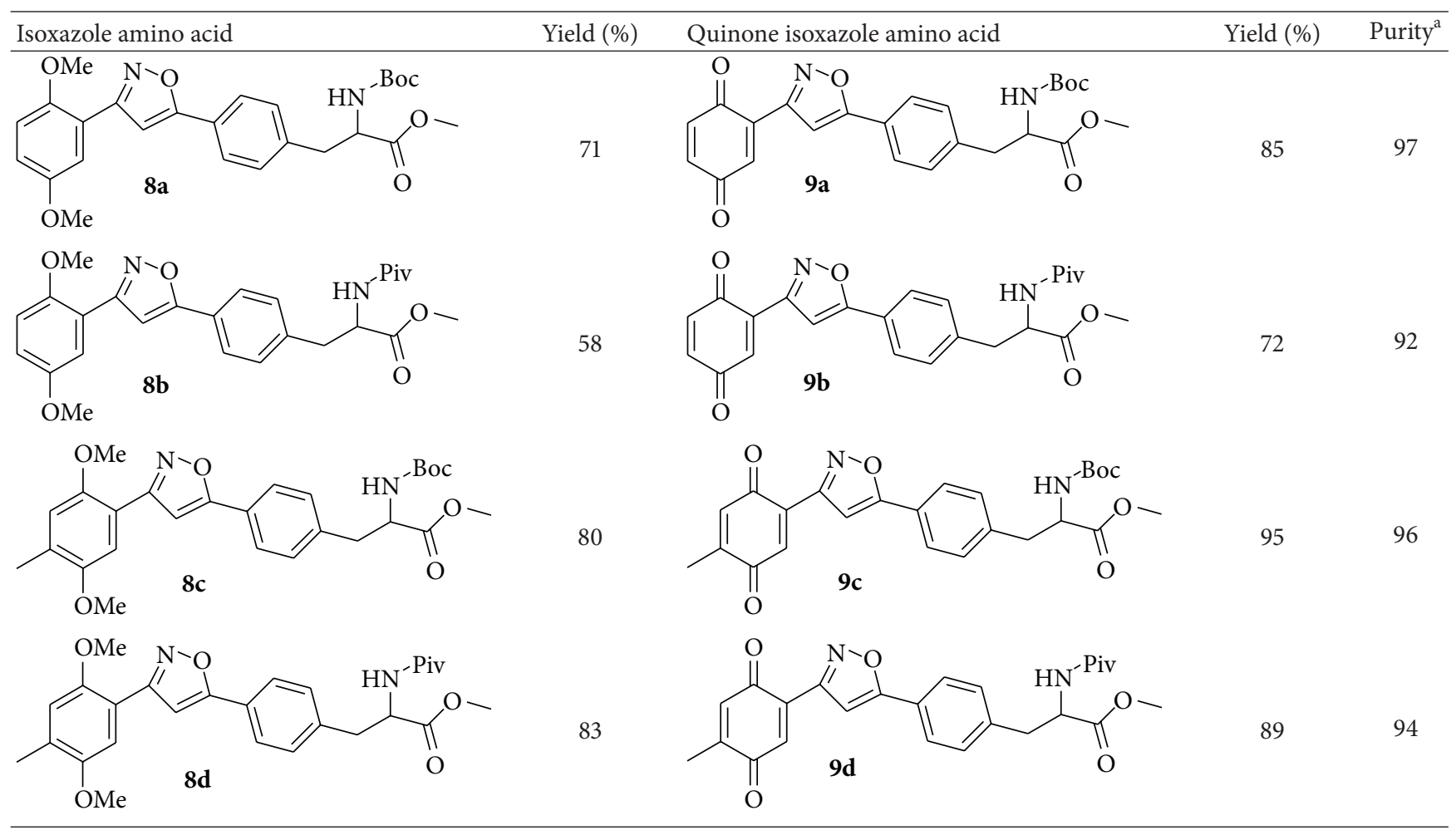

${ }^{\mathrm{a}}$ Combined purity of hydroquinone and quinone by LC-MS analysis.

$\mathrm{PdCl}_{2}\left(\mathrm{PPh}_{3}\right)_{2}$ in reflux condition to give compound $\mathbf{4 a}$ or $\mathbf{4 b}$ (Scheme 1). Then TMS group was deprotected using TBAF to give the key acetylenic amino acid ready for cycloaddition reaction. 2,5-Dimethoxy benzaldehyde $\mathbf{6 a}$ or $\mathbf{6 b}$ reacted with hydroxylamine hydrochloride $\left(\mathrm{NH}_{2} \mathrm{OH} \cdot \mathrm{HCl}\right)$ to produce the oxime derivative $7 \mathbf{a}$ or $7 \mathbf{b}$. The compound $7 \mathbf{a}$ or $\mathbf{7 b}$ was subjected to the key 1,3-dipolar cycloaddition reaction with actetylenic amino acid $\mathbf{5 a}$ or $\mathbf{5 b}$ in the presence of $\mathrm{NaOCl} / \mathrm{Et}_{3} \mathrm{~N}$ in $\mathrm{DCM}$ as solvent. The isoxazoles 8a-d were smoothly formed using this Huisgen's one pot protocol. We did not observe the formation of any other isomer and nitrile oxide dimerization product in this reaction. Any undesired by-products resulting from aromatic halogenations reaction were not observed in our case.

Then the compound $\mathbf{8 a}$ was oxidized with CAN to give the desired isoxazole tethered quinone-amino acid $\mathbf{9 a}$ in very good yield. The compound 9 a was characterized by ${ }^{1} \mathrm{H}-$ NMR, ${ }^{13} \mathrm{C}-\mathrm{NMR}$, and HRMS. For example, the characteristic isoxazole proton at $7.1 \delta$ and quinone proton at $6.8 \delta$ in ${ }^{1} \mathrm{H}$ NMR confirms the oxidation of compound $\mathbf{8 a}$ to generate compound 9a. The two carbonyl peaks at 186.8 and $185.2 \delta$ in ${ }^{13} \mathrm{C}$-NMR spectrum validate the benzoquinone moiety. Using similar sequence (Scheme 1) the target compounds $\mathbf{9 b -}$ d (Table 1) were prepared and characterized by spectral data. The isoxazole tethered quinone-amino acids show equilibrium between hydroquinone (9ah) and benzoquinone (9a) in liquid chromatography mass spectrometry (LC-MS) analysis condition as shown in Figure 3. It may be possible that benzoquinone forms a reduced species during the ionization process in LC-MS condition [49].

Encouraged by this result, we turn our attention to the preparation of propargyl amino acid as starting material. Various acetylene building blocks containing an amino acid moiety were prepared from Schiff-base $\mathrm{N}$-(diphenylmethylene)glycine ester $\mathbf{1 0}$ using the literature procedure [50]. Thus, alkylation of $\mathbf{1 0}$ with propargyl bromide 11 in the presence of $\mathrm{K}_{2} \mathrm{CO}_{3} / \mathrm{CH}_{3} \mathrm{CN}$ in reflux condition gave the propargylated derivative 12. Then the compound 12 was subjected to 1,3-dipolar cycloaddition reaction with the oxime $7 \mathbf{a}$ in the presence of $\mathrm{NCS} / \mathrm{NaHCO}_{3}$ in ethyl acetate as solvent to give very low yield of the compound 17a (Scheme 2). We tried couple of conditions to improve the yield of compound 17a but without any success. Maybe either steric factor or the instability of compound $\mathbf{1 2}$ is the main reason behind the low yield of the cycloaddition product. Then we turn our attention to the compound 13 which was prepared from compound $\mathbf{1 2}$ by hydrolysis reaction followed by protection of the amino group. We tried several conditions (Table 2) to improve the yield of the compound 19b without any success.

Alternatively we plan to introduce the amino acid at the end of reaction sequence to prepare the isoxazole tethered quinone-amino acid hybrid (Scheme 3). Thus, the oxime derivative $7 \mathbf{a}$ or $\mathbf{7 b}$ was subjected to cycloaddition reaction with propargyl alcohol 14 using $\mathrm{NCS} / \mathrm{NaHCO}_{3}$ condition in ethyl acetate as solvent. Under this reaction condition, the 3-aryl-isoxazole derivative $\mathbf{1 5 a}$ or $\mathbf{1 5 b}$ was prepared in good 
TABLE 2: The yields of the compound $19 \mathrm{~b}$ using various 1,3-cycloaddition reaction conditions.

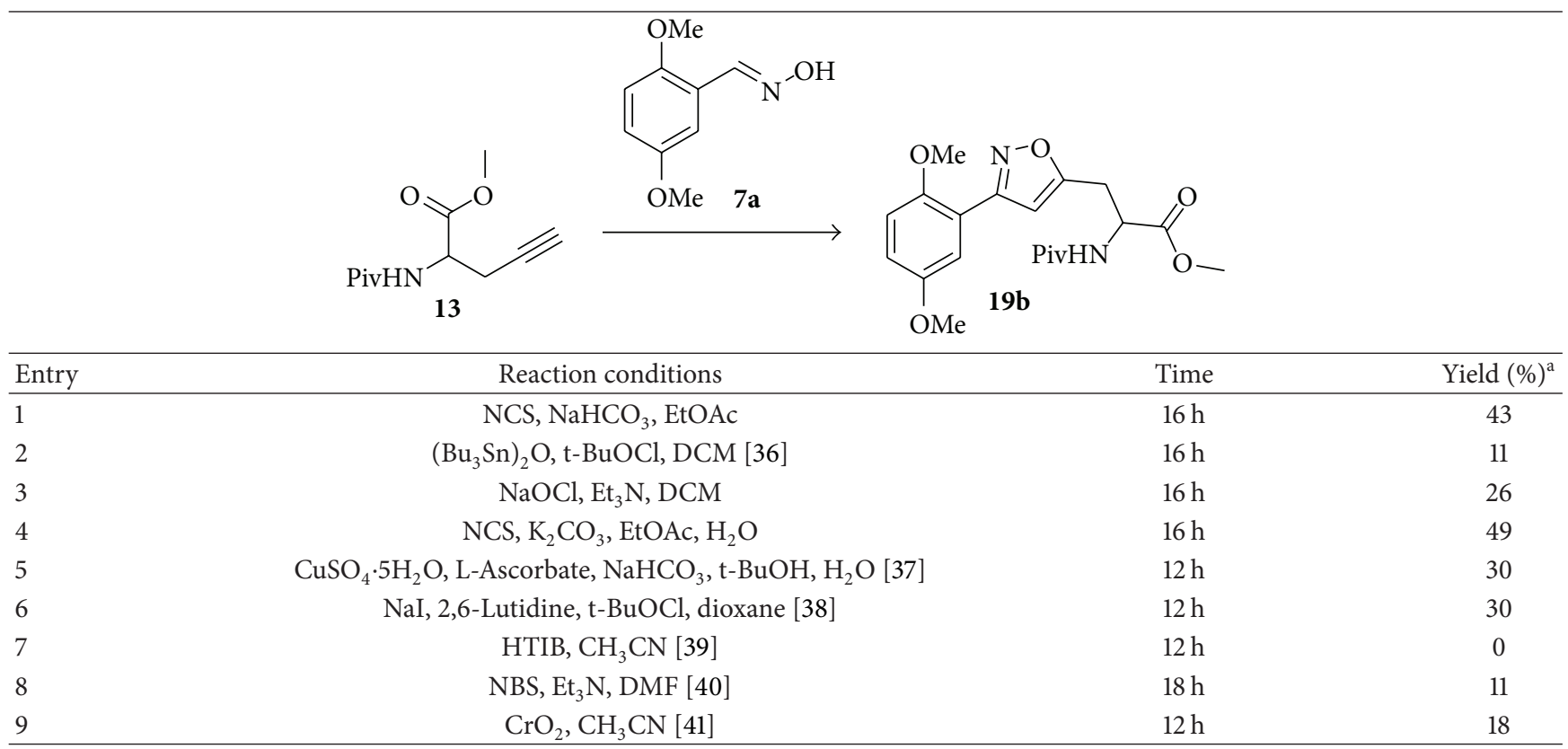

${ }^{a}$ Determined by analysis of the crude reaction mixture by analytical LC/MS.

HTIB: hydroxy(tosyloxy)iodobenzene; NCS: N-chloro succinamide; NBS: N-bromosuccinamide.

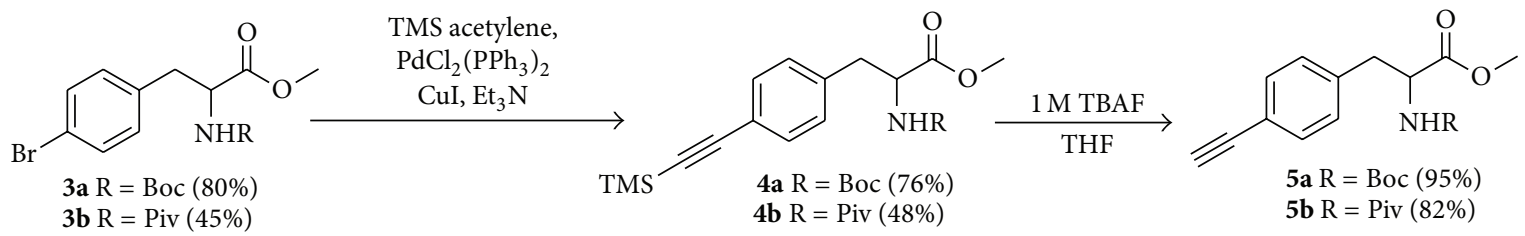

3a $\mathrm{R}=\operatorname{Boc}(80 \%)$ 4b R $=\operatorname{Piv}(48 \%)$

$\mathbf{5 b} \mathrm{R}=\operatorname{Piv}(82 \%)$
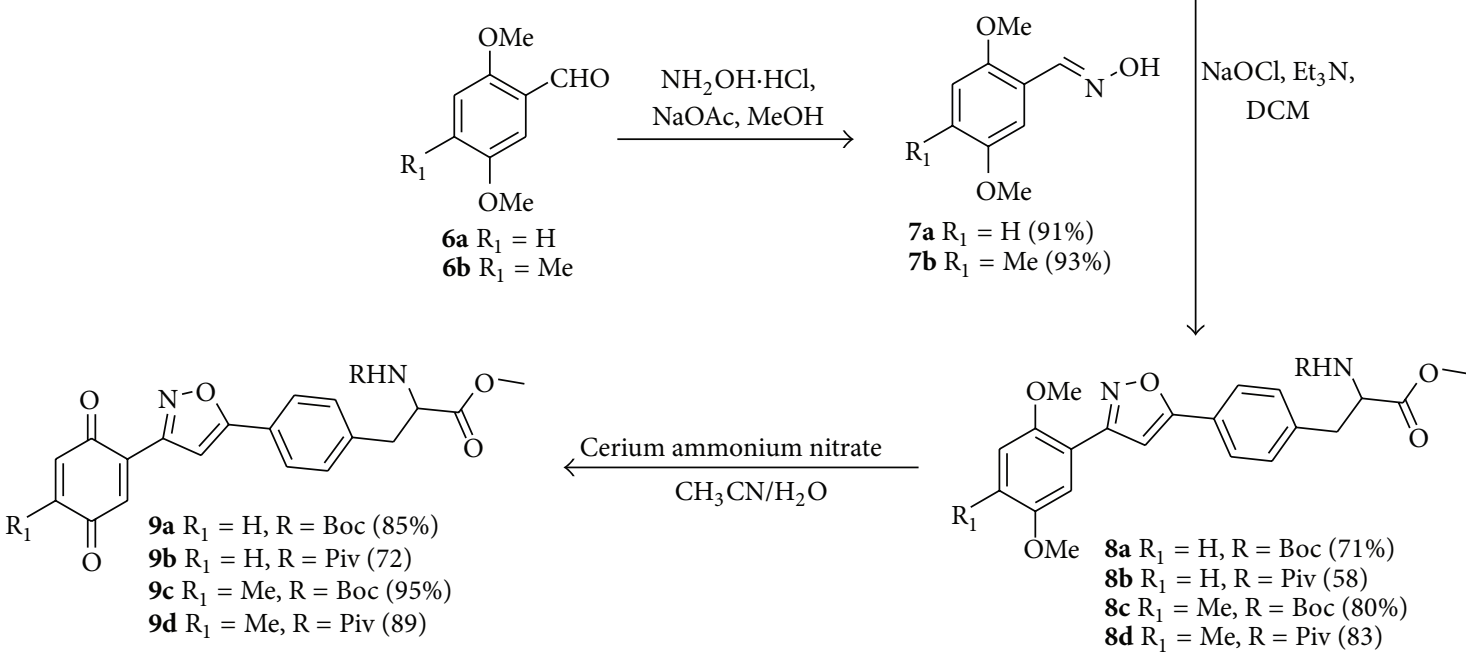

Scheme 1: Synthesis of isoxazole tethered quinone phenylalanine hybrids.

yield. Then the hydroxyl methyl group in the compound 15a or 15b was converted to bromo methyl group using $\mathrm{PBr}_{3} / \mathrm{DCM}$ condition to give the compound $\mathbf{1 6 a}$ or $\mathbf{1 6} \mathbf{b}$.

Gratifyingly, the key step alkylation reaction of $\mathbf{1 0}$ with compound 16a in the presence of $\mathrm{K}_{2} \mathrm{CO}_{3} / \mathrm{CH}_{3} \mathrm{CN}$ in reflux condition gave the 3,5-substituted isoxazole derivative 17 a or 17b. The compound 17a was hydrolyzed in the presence of $1 \mathrm{~N} \mathrm{HCl}$ /diethyl ether and the resulting amino ester 18a was protected with either $\mathrm{Boc}_{2} \mathrm{O}$ or pivaloyl chloride to obtain Boc derivative 19a or pivaloyl derivative 19b, respectively. 


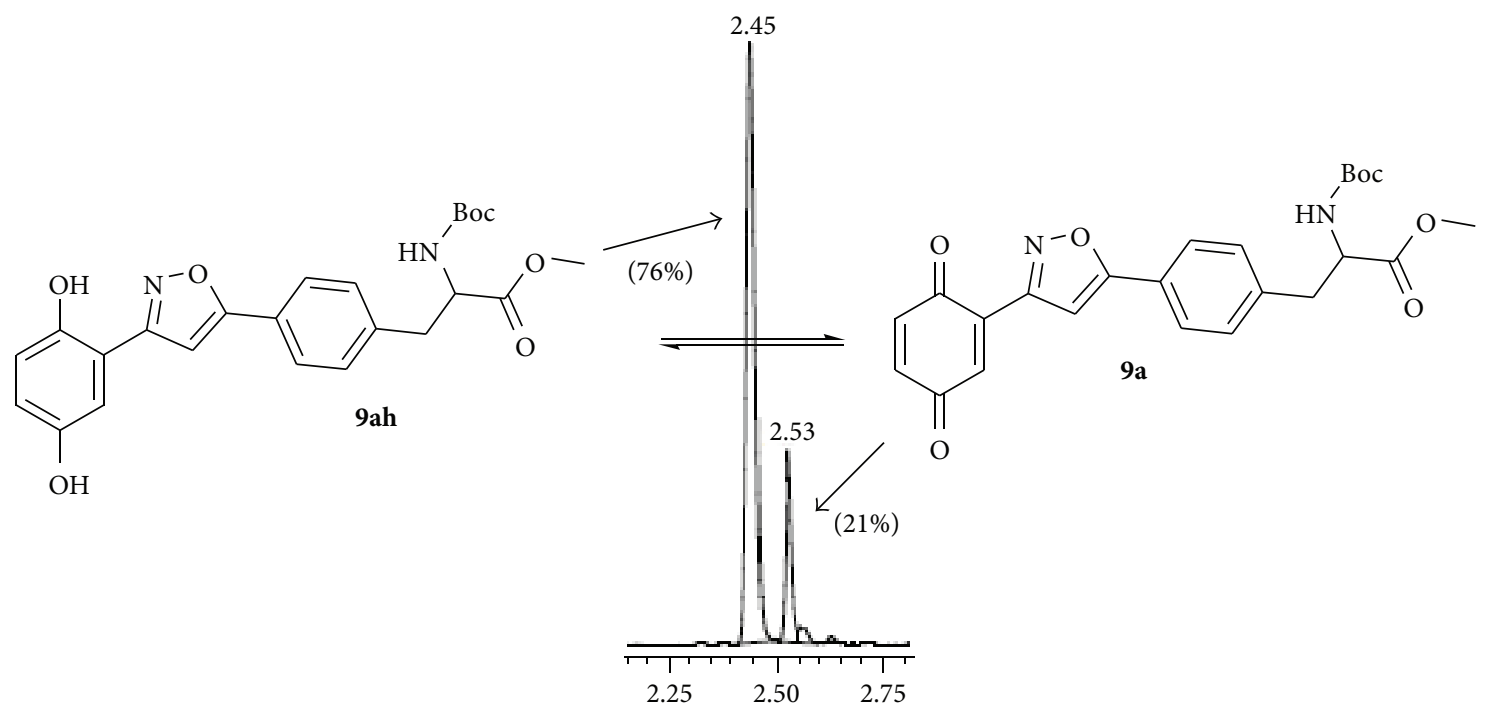

FIGURE 3: LC-MS analysis of compound 9a (showing the integrated percentage).<smiles>C#CCC(N=C(c1ccccc1)c1ccccc1)C(=O)OC</smiles>

Scheme 2: Synthesis of 3,5-disubstituted isoxazole derivative.

Then the compound 19a was oxidized with CAN to give the desired target isoxazole tethered quinone amino acid 20a in very good yield. The compound $\mathbf{2 0 a}$ was characterized by ${ }^{1} \mathrm{H}-\mathrm{NMR},{ }^{13} \mathrm{C}-\mathrm{NMR}$, and HRMS spectral data. In a similar sequence the target compounds $\mathbf{2 0 b}$-d were prepared and characterized by spectral data. The purity of the final isoxazole tethered quinone amino acids (Table 3 ) was obtained by LC-MS analysis which showed equilibrium between quinone and hydroquinone as observed earlier(Figure 3).

It is noteworthy to mention here that previously inaccessible quinone amino acids (19a-d and 20a-d) containing isoxazole moiety were synthesized in very good yield. As indicated in Table 3, the proting group (Boc or pivaloyl) has no effect on the yield of cycloaddition as well as oxidation reaction to give the isoxazole tethered quinone amino acids.
In conclusion, we have developed an efficient and simple method to synthesize isoxazole tethered quinone-amino acid hybrids using 1,3-dipolar cycloaddition and oxidation reactions as key steps in good yields. We believe that this methodology will find a widespread application for the synthesis of 2-aryl-benzoquinone and its derivatives. Further application of this methodology for the synthesis of isoxazole tethered quinone-peptide hybrid as well as preparation of tetrazole tethered quinone-amino acid hybrid is undergoing in our group.

\section{Conflict of Interests}

The authors declare that there is no conflict of interests regarding the publication of this paper. 
TABLE 3: The yields and purity of the novel isoxazole-glycine and isoxazole tethered quinone-glycine hybrids.

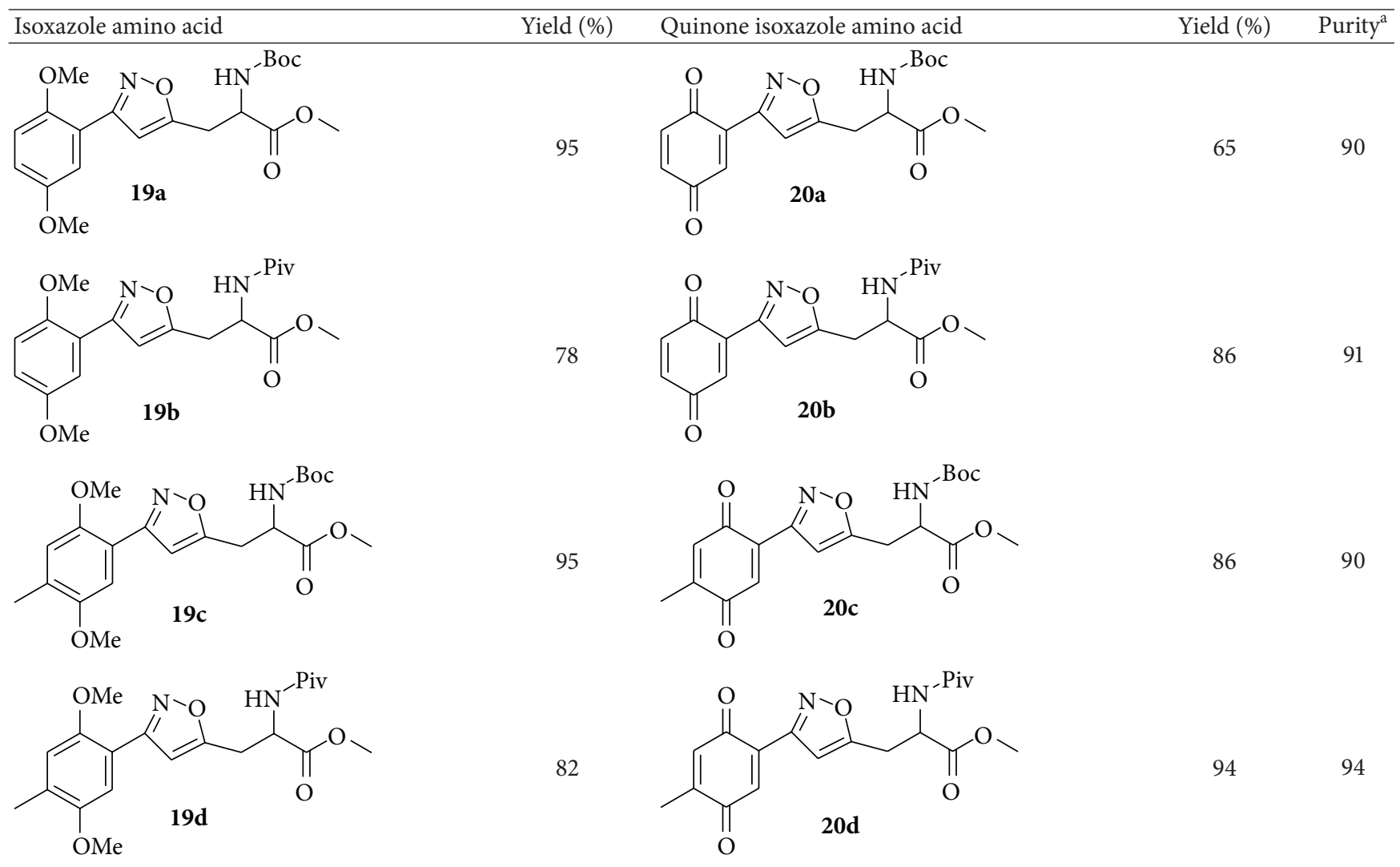

${ }^{\mathrm{a}}$ Combined purity of hydroquinone and quinone by LC-MS analysis.

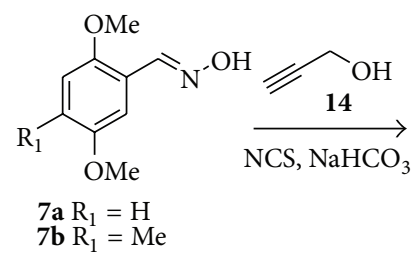

$7 \mathbf{a} \mathrm{R}_{1}=\mathrm{H}$
$7 \mathbf{b} \mathrm{R}_{1}=\mathrm{Me}$<smiles>[R]c1cc(OC)c(-c2cc(CO)on2)cc1OCC(Br)=[W]</smiles>

$15 b \mathrm{R}_{1}=\mathrm{Me}(90 \%)$

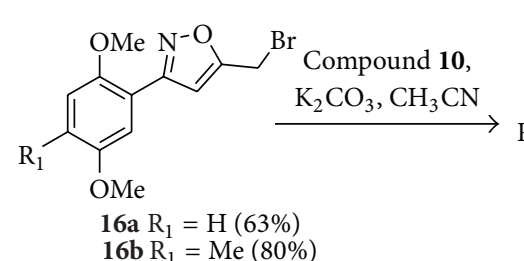

$1 \mathrm{M} \mathrm{HCl}$, diethyl ether

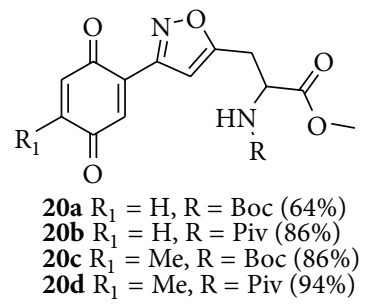
$\stackrel{\mathrm{CAN} \cdot \mathrm{CH}_{3} \mathrm{CN}}{\longleftarrow}$<smiles>[R]NC(Cc1cc(-c2cc(OC)c([R])cc2OC)no1)C(=O)OC</smiles>

19a $\mathrm{R}_{1}=\mathrm{H}, \mathrm{R}=\operatorname{Boc}(95 \%)$

19b $\mathrm{R}_{1}=\mathrm{H}, \mathrm{R}=\operatorname{Piv}(78 \%)$

$19 \mathrm{c} \mathrm{R}_{1}=\mathrm{Me}, \mathrm{R}=\operatorname{Boc}(95 \%)$

19d $\mathrm{R}_{1}=\mathrm{Me}, \mathrm{R}=\operatorname{Piv}(82 \%)$

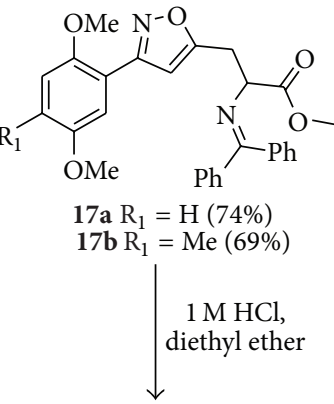

SCHEme 3: Synthesis of isoxazole tethered glycine quinone hybrids.

\section{Acknowledgments}

The authors are grateful to GVK Biosciences Pvt. Ltd., for the financial support and encouragement. Help from the analytical department for the analytical data is appreciated. The authors thank Dr. Sudhir Kumar Singh for his invaluable support and motivation.

\section{References}

[1] P. M. Dewick, Medicinal Natural Products, Chichester, UK, Wiley, 2nd edition, 2002.

[2] Y. Kimura, "New anticancer agents: In vitro and in vivo evaluation of the antitumor and antimetastatic actions of various compounds isolated from medicinal plants," In Vivo, vol. 19, no. 1, pp. 37-60, 2005. 
[3] B. Nowicka and J. Kruk, "Occurrence, biosynthesis and function of isoprenoid quinones," Biochimica et Biophysica Acta, vol. 1797, no. 9, pp. 1587-1605, 2010.

[4] Z. S. Saify, N. Mushtaq, F. Noor, S. Takween, and M. Arif, "Role of quinone moiety as antitumour agtents: a review," Pakistan Journal of Pharmaceutical Sciences, vol. 12, no. 2, pp. 21-31, 1999.

[5] D. R. A. Mans, J. Retel, J. M. S. van Maanen et al., "Role of the semi-quinone free radical of the anti-tumour agent etoposide (VP-16-213) in the inactivation of single- and double-stranded ФX174 DNA," British Journal of Cancer, vol. 62, no. 1, pp. 54-60, 1990.

[6] K. Ishiguro, K. Takahashi, K. Yazawa, S. Sakiyama, and T. Arai, "Binding of saframycin A, a heterocyclic quinone anti-tumor antibiotic to DNA as revealed by the use of the antibiotic labeled with [14C]tyrosine or [14C]cyanide," The Journal of Biological Chemistry, vol. 256, no. 5, pp. 2162-2167, 1981.

[7] D. L. Boger, M. Yasuda, L. A. Mitscher, S. D. Drake, P. A. Kitos, and S. C. Thompson, "Streptonigrin and lavendamycin partial structures. Probes for the minimum, potent pharmacophore of streptonigrin, lavendamycin, and synthetic quinoline-5,8diones," Journal of Medicinal Chemistry, vol. 30, no. 10, pp. 19181928, 1987.

[8] W. J. Pigram, W. Fuller, and L. D. Hamilton, "Stereochemistry of intercalation: interaction of daunomycin with DNA," Nature: New Biology, vol. 235, no. 7, pp. 17-19, 1972.

[9] V. N. Iyer and W. Szybalski, "Mitomycins and porfiromycin: chemical mechanism of activation and cross-linking of DNA," Science, vol. 145, no. 3627, pp. 55-58, 1964.

[10] R. Cone, S. K. Hasan, J. W. Lown, and A. R. Morgan, "The mechanism of the degradation of DNA by streptonigrin," Canadian Journal of Biochemistry, vol. 54, no. 3, pp. 219-223, 1976.

[11] P. Conti, M. de Amici, G. Grazioso et al., "Synthesis, binding affinity at glutamic acid receptors, neuroprotective effects, and molecular modeling investigation of novel dihydroisoxazole amino acids," Journal of Medicinal Chemistry, vol. 48, no. 20, pp. 6315-6325, 2005.

[12] S. Srivastava, L. K. Bajpai, S. Batra et al., "In search of new chemical entities with spermicidal and anti-HIV activities," Bioorganic and Medicinal Chemistry, vol. 7, no. 11, pp. 2607-2613, 1999.

[13] A. Kumar, R. A. Maurya, S. Sharma et al., "Design and synthesis of 3,5-diarylisoxazole derivatives as novel class of anti-hyperglycemic and lipid lowering agents," Bioorganic and Medicinal Chemistry, vol. 17, no. 14, pp. 5285-5292, 2009.

[14] T. Karabasanagouda, A. V. Adhikari, and M. Girisha, "Synthesis of some new pyrazolines and isoxazoles carrying 4methylthiophenyl moiety as potential analgesic and antiinflammatory agents," Indian Journal of Chemistry-Section B Organic and Medicinal Chemistry, vol. 48, no. 3, pp. 430-437, 2009.

[15] B. R. Dravyakar, D. P. Kawade, P. B. Khedekar, and K. P. Bhusari, "Design and syntheses of some new diphenylaminoisoxazolines as potent anti-inflammatory agent," Indian Journal of Chemistry B: Organic and Medicinal Chemistry, vol. 47, no. 10, pp. 15591567, 2008.

[16] S. B. Jadhav, R. A. Shastri, K. V. Gaikwad, and S. V. Gaikwad, "Synthesis and antimicrobial studies of some novel pyrazoline and isoxazoline derivatives," E-Journal of Chemistry, vol. 6, supplement 1, pp. S183-S188, 2009.

[17] J. J. Talley, D. L. Brown, J. S. Carter et al., "4-[5-Methyl3-phenylisoxazol-4-yl]-benzenesulfonamide, Valdecoxib: a potent and selective inhibitor of COX-2," Journal of Medicinal Chemistry, vol. 43, no. 5, pp. 775-777, 2000.

[18] T. M. V. D. Pinho e Melo, "Recent advances on the synthesis and reactivity of isoxazoles," Current Organic Chemistry, vol. 9, no. 10, pp. 925-958, 2005.

[19] A. R. Katritzky, M. A. C. Button, and S. N. Denisenko, "Efficient synthesis of 3,5-functionalized isoxazoles and isoxazolines via 1,3-dipolar cycloaddition reactions of 1-propargyl- and 1allylbenzotriazoles," Journal of Heterocyclic Chemistry, vol. 37, no. 6, pp. 1505-1510, 2000.

[20] S. Kotha, "The building block approach to unusual $\alpha$-amino acid derivatives and peptides," Accounts of Chemical Research, vol. 36, no. 5, pp. 342-351, 2003.

[21] D. A. Dougherty, "Unnatural amino acids as probes of protein structure and function," Current Opinion in Chemical Biology, vol. 4, no. 6, pp. 645-652, 2000.

[22] M. J. O'Donnell, “The preparation of optically active $\alpha$-amino acids from the benzophenone imines of glycine derivatives," Aldrichimica Acta, vol. 34, no. 1, pp. 3-15, 2001.

[23] T. Hashimoto and K. Maruoka, "Recent development and application of chiral phase-transfer catalysts," Chemical Reviews, vol. 107, no. 12, pp. 5656-5682, 2007.

[24] L. F. Tietze, H. P. Bell, and S. Chandrasekhar, "Natural product hybrids as new leads for drug discovery," Angewandte Chemie, vol. 42, no. 34, pp. 3996-4028, 2003.

[25] G. Mehta and V. Singh, "Hybrid systems through natural product leads: an approach towards new molecular entities," Chemical Society Reviews, vol. 31, no. 6, pp. 324-334, 2002.

[26] M. Decker, "Hybrid molecules incorporating natural products: applications in cancer therapy, neurodegenerative disorders and beyond," Current Medicinal Chemistry, vol. 18, no. 10, pp. 14641475, 2011.

[27] S. Kotha, K. Mandal, S. Banerjee, and S. M. Mobin, "Synthesis of novel quinone-amino acid hybrids via cross-enyne metathesis and Diels-Alder reaction as key steps," European Journal of Organic Chemistry, no. 8, pp. 1244-1255, 2007.

[28] K. P. Kaliappan and V. Ravikumar, "Design and synthesis of novel sugar-oxasteroid-quinone hybrids," Organic and Biomolecular Chemistry, vol. 3, no. 5, pp. 848-851, 2005.

[29] S. Hoppen, U. Emde, T. Friedrich, L. Grubert, and U. Koert, "Natural product hybrids: design, synthesis and biological evaluation of quinone-annonaceous acetogenins," Angewandte Chemie International Edition in English, vol. 39, no. 12, pp. 2099$2102,2000$.

[30] G. Mehta and S. S. Ramesh, "Polycyclitols - Novel conduritol and carbasugar hybrids as new glycosidase inhibitors," Canadian Journal of Chemistry, vol. 83, no. 6-7, pp. 581-594, 2005.

[31] P. R. Kumar, M. Behera, K. Raghavulu, A. J. Shree, and S. Yennam, "Synthesis of novel isoxazole-benzoquinone hybrids via 1,3-dipolar cycloaddition reaction as key step," Tetrahedron Letters, vol. 53, no. 32, pp. 4108-4113, 2012.

[32] D. J. Burkhart, B. Twamley, and N. R. Natale, "A new direct synthesis of ACPA and novel AMPA analogues," Tetrahedron Letters, vol. 42, no. 48, pp. 8415-8418, 2001.

[33] D. Schulz, P. Beese, B. Ohlendorf et al., "Abenquines A-D: aminoquinone derivatives produced by Streptomyces sp. strain DB634," Journal of Antibiotics, vol. 64, no. 12, pp. 763-768, 2011.

[34] J. Sakaki, T. Murata, Y. Yuumoto et al., "Discovery of IRL 3461: a novel and potent endothelin antagonist with balanced $\mathrm{ET}_{A} / \mathrm{ET}_{B}$ affinity," Bioorganic and Medicinal Chemistry Letters, vol. 8, no. 16, pp. 2241-2246, 1998. 
[35] A. R. Katritzky, L. Huang, and R. Sakhuja, "Efficient syntheses of naphthoquinone-dipeptides," Synthesis, no. 12, Article ID M06709SS, pp. 2011-2016, 2010.

[36] O. Moriya, H. Takenaka, M. Iyoda, Y. Urata, and T. Endo, "Generation of nitrite oxides via O-tributylstannyl aldoximes, application to the synthesis of isoxazolines and isoxazoles," Journal of the Chemical Society Perkin Transactions I, no. 4, pp. 413-417, 1994.

[37] F. Himo, T. Lovell, R. Hilgraf et al., "Copper(I)-catalyzed synthesis of azoles. DFT study predicts unprecedented reactivity and intermediates," Journal of the American Chemical Society, vol. 127, no. 1, pp. 210-216, 2005.

[38] S. Minakata, S. Okumura, T. Nagamachi, and Y. Takeda, "Generation of nitrile oxides from oximes using $\mathrm{t}-\mathrm{BuOI}$ and their cycloaddition," Organic Letters, vol. 13, no. 11, pp. 29662969, 2011.

[39] R. D. Jadhav, H. D. Mistry, H. Motiwala et al., "A facile onepot synthesis of 3,5-disubstituted isoxazole derivatives using hydroxy (tosyloxy) iodobenzene," Journal of Heterocyclic Chemistry, vol. 50, no. 4, pp. 774-780, 2013.

[40] A. Dondoni, P. P. Giovannini, and A. Massi, "Assembling heterocycle-tethered $C$-glycosyl and $\alpha$-amino acid residues via 1,3-dipolar cycloaddition reactions," Organic Letters, vol. 6, no. 17, pp. 2929-2932, 2004.

[41] S. Bhosale, S. Kurhade, U. V. Prasad, V. P. Palle, and D. Bhuniya, "Efficient synthesis of isoxazoles and isoxazolines from aldoximes using Magtrieve $\mathrm{CrO}_{2}$," Tetrahedron Letters, vol. 50, no. 27, pp. 3948-3951, 2009.

[42] R. Huisgen, "1,3-Dipolar cycloaddition. Past and future," Angewandte Chemie International Edition, vol. 2, no. 10, pp. 565-568, 1963.

[43] S. Kanemasa and O. Tsuge, "Recent advances in synthetic applications of nitrile oxide cycloaddition (1981-1989)," Heterocycles, vol. 30, no. 1, pp. 719-736, 1990.

[44] L. M. Stanley and M. P. Sibi, "Enantioselective copper-catalyzed 1,3-dipolar cycloadditions," Chemical Reviews, vol.108, no. 8, pp. 2887-2902, 2008.

[45] R. Sustmann, "Rolf Huisgen's contribution to organic chemistry, emphasizing 1,3-dipolar cycloadditions," Heterocycles, vol. 40, no. 1, pp. 1-18, 1995.

[46] M. J. O'Donnell, K. Wojciechowski, L. Ghosez, M. Navarro, F. Sainte, and J. P. Antoine, "Alkylation of protected a-amino acid derivatives in the presence of potassium carbonate," Synthesis, no. 4, pp. 313-315, 1984.

[47] M. J. O’Donnell, W. D. Bennett, and S. Wu, “The stereoselective synthesis of $\alpha$-amino acids by phase-transfer catalysis," Journal of the American Chemical Society, vol. 111, no. 6, pp. 2353-2355, 1989.

[48] M. J. O’Donnell, F. Delgado, and R. S. Pottorf, "Enantioselective solid-phase synthesis of $\alpha$-amino acid derivatives," Tetrahedron, vol. 55, no. 20, pp. 6347-6362, 1999.

[49] B. M. Hoey, J. Butler, and A. J. Swallow, "Reductive activation of mitomycin C," Biochemistry, vol. 27, no. 7, pp. 2608-2614, 1988.

[50] P. Nun, V. Pérez, M. Calmès, J. Martinez, and F. Lamaty, "Preparation of chiral amino esters by asymmetric phasetransfer catalyzed alkylations of schiff bases in a ball mill," Chemistry - A European Journal, vol. 18, no. 12, pp. 3773-3779, 2012. 

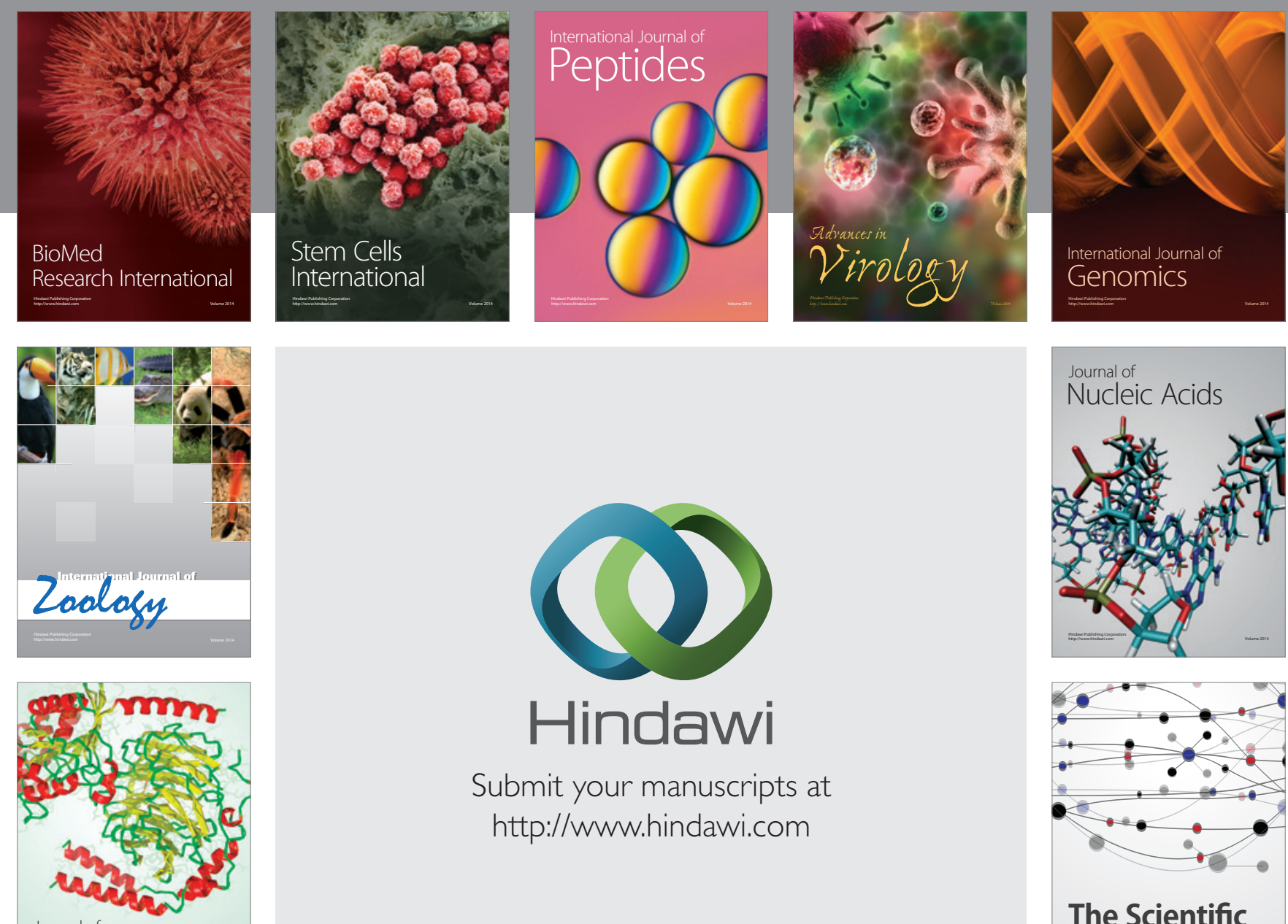

Submit your manuscripts at

http://www.hindawi.com

Journal of
Signal Transduction
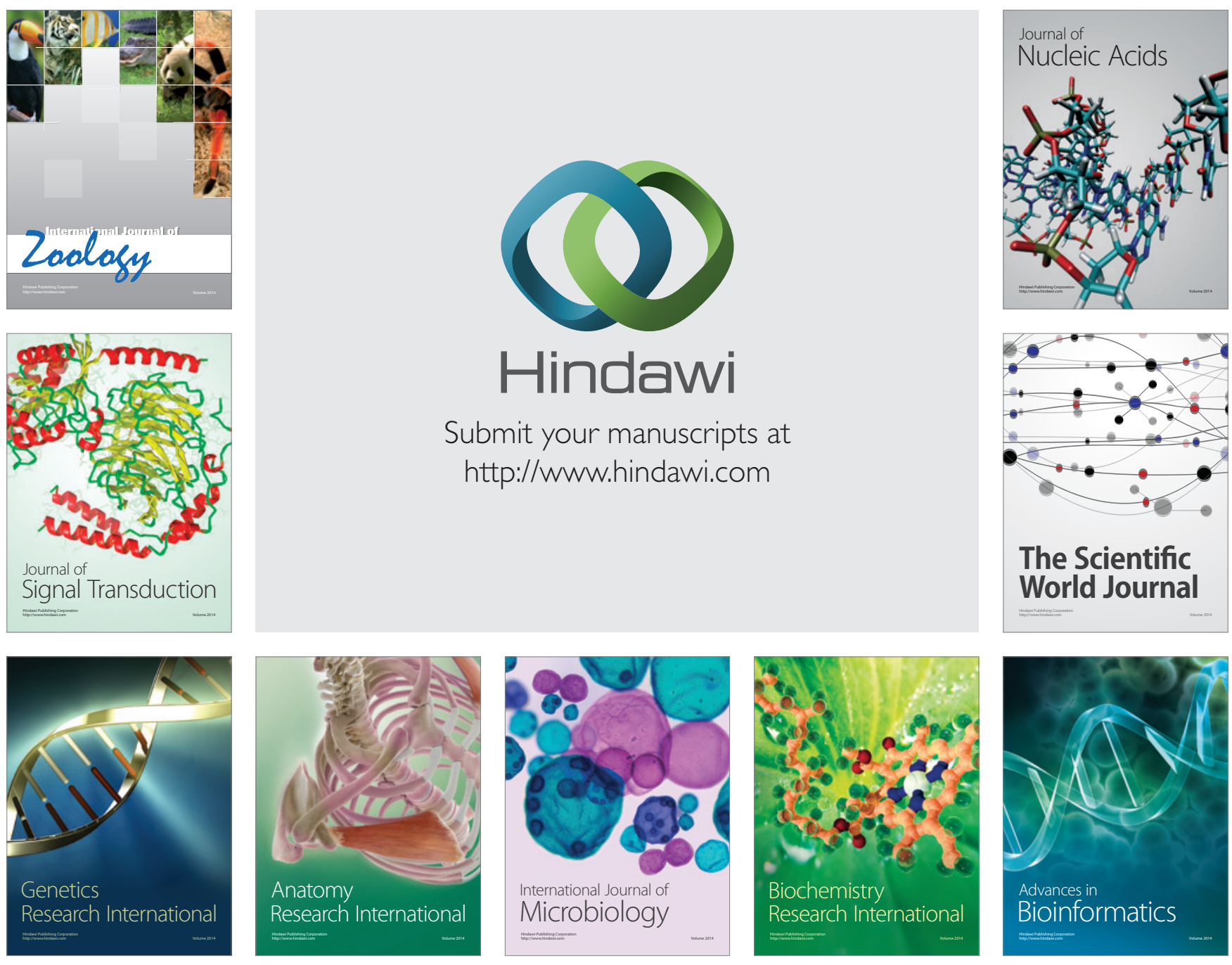

The Scientific World Journal
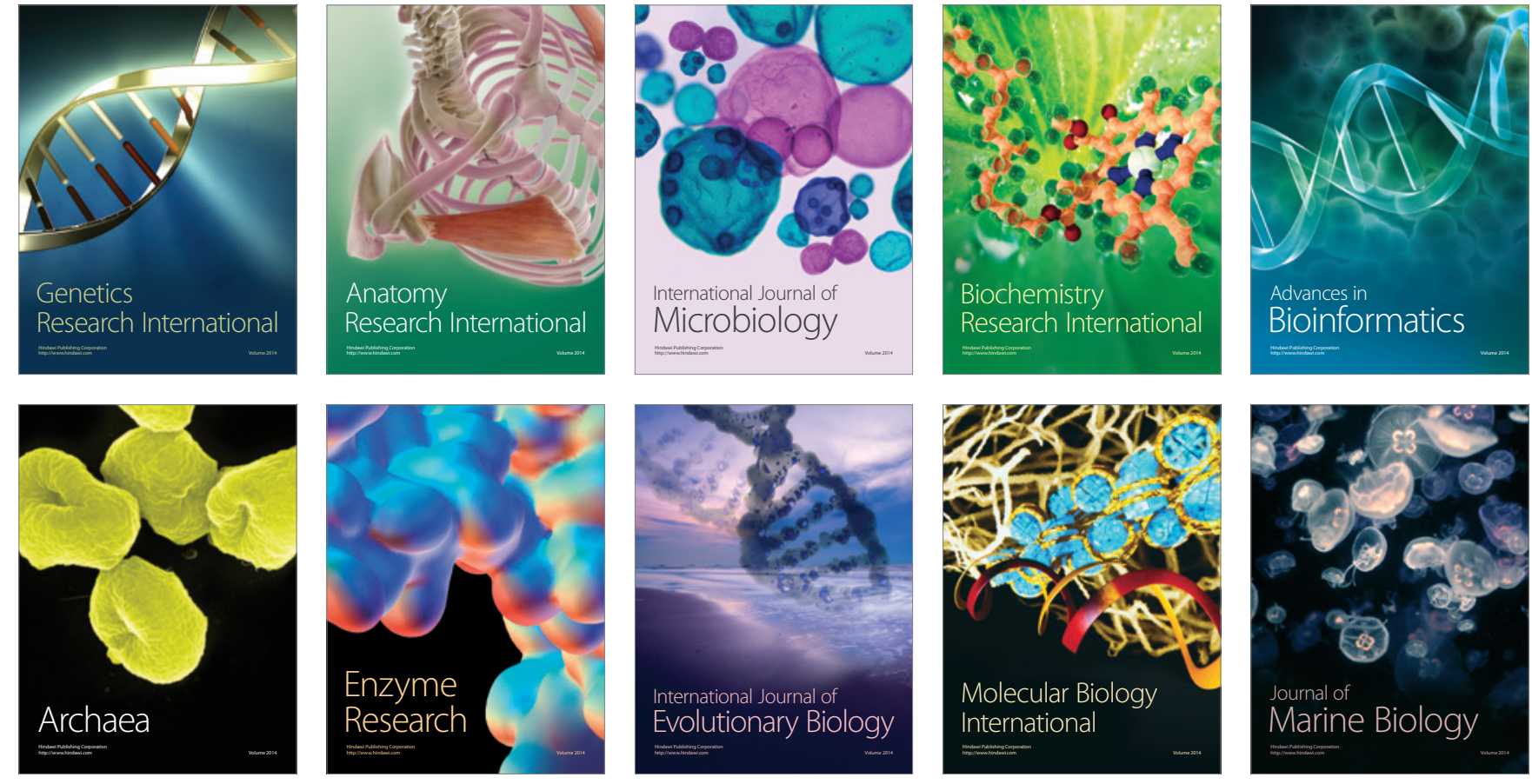